\title{
Krzysztof Siewicz
}

\section{Otwarty dostęp do publikacji naukowych kwestie prawne}




\section{Otwarty dostęp do publikacji naukowych}




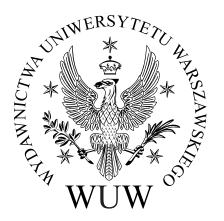

Krzysztof Siewicz

Otwarty dostęp do publikacji naukowych kwestie prawne 
Projekt graficzny okładki i stron tytułowych Jakub Rakusa-Suszczewski

Skład i łamanie Dariusz Górski

(C) Copyright by Interdyscyplinarne Centrum Modelowania Matematycznego i Komputerowego Uniwersytetu Warszawskiego, Warszawa 2012. Pewne prawa zastrzeżone. Tekst niniejszej publikacji jest dostępny na licencji Creative Commons - Uznanie autorstwa 3.0 Polska. Postanowienia licencji są dostępne pod http://creativecommons.org/licenses/by/3.0/pl/legalcode

\section{WYDAWCA}

WYDAWNICTWA UNIWERSYTETU WARSZAWSKIEGO

00-497 Warszawa, ul. Nowy Świat 4

www.wuw.pl; e-mail: wuw@uw.edu.pl

Dział Handlowy: tel. 225531333

e-mail: dz.handlowy@uw.edu.pl

Księgarnia internetowa: www.wuw.pl/ksiegarnia

ISBN 978-83-235-0959-2

ISBN 978-83-235-0967-7 (PDF)

Druk i oprawa Zakład Graficzny UW. Zam. 1113/12 


\section{Spis treści}

1 Wprowadzenie. ...................... 7

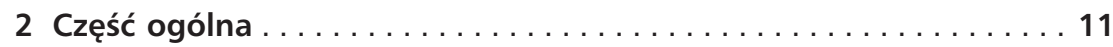

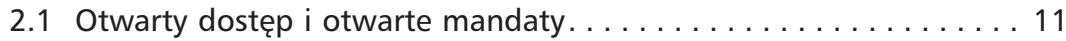

Prawnicza definicja otwartego dostępu . . . . . . . . . . 11

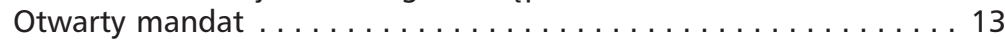

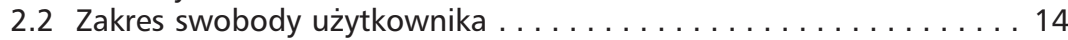

Swobody użytkownika w otwartym dostępie gratis . . . . . . . 14

Swobody użytkownika $w$ otwartym dostępie libre . . . . . . . 15

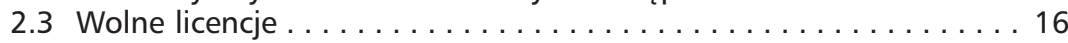

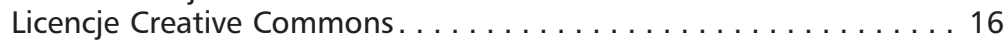

Klauzule licencji CC . . . . . . . . . . . . . . . . . . 17

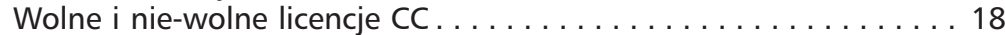

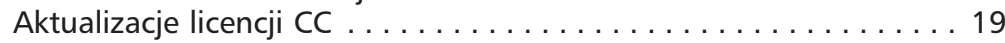

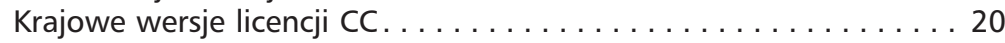

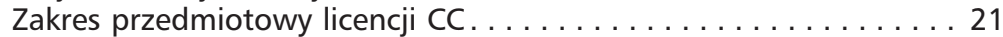

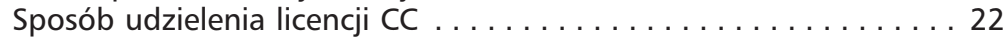

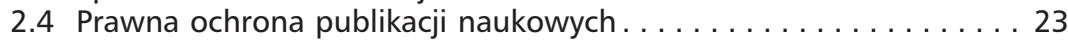

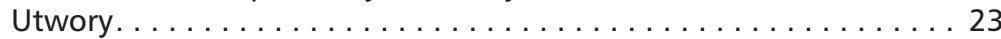

Programy komputerowe .................. 23

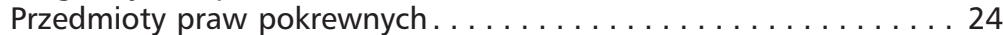

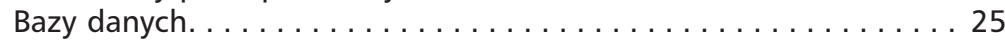

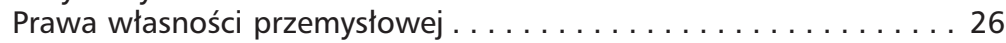

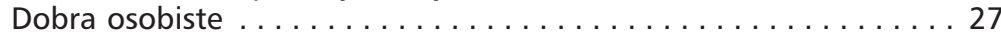

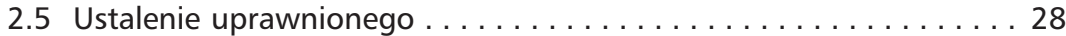

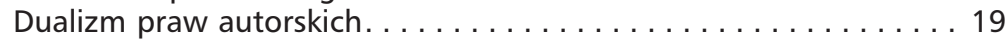

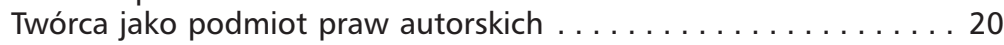

Utwory pracownicze .................... 20

Pracownicze utwory naukowe. . . . . . . . . . . . 30

Pracownicze programy komputerowe i bazy danych . . . . . . 31

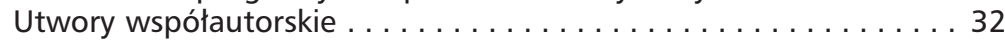

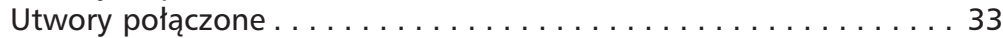

Utwory zbiorowe....................... 34 


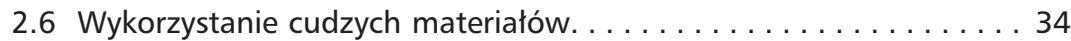

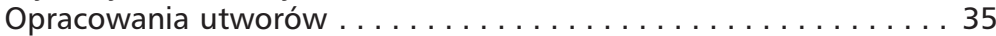

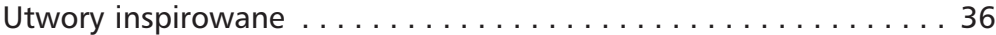

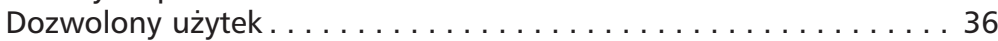

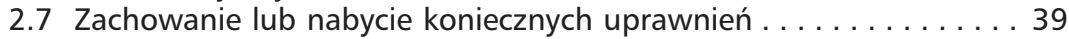

Umowy z zakresu prawa autorskiego . . . . . . . . . . . . . . 39

Zakres praw koniecznych dla otwartego dostępu gratis........ 40

Zakres praw koniecznych dla otwartego dostępu libre. . . . . . . 41

3 Wdrażanie otwartego dostępu z perspektywy autora. . . . . . . 43

3.1 Ustalenie uprawnionego $\ldots \ldots \ldots \ldots \ldots \ldots \ldots \ldots \ldots \ldots \ldots$

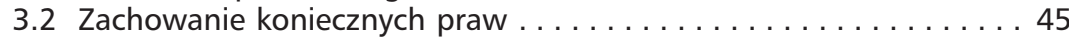

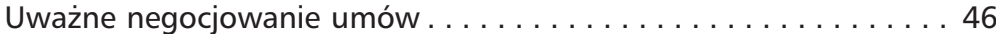

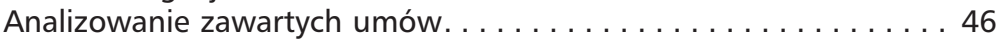

Aneksowanie lub rozwiązywanie umów za porozumieniem stron . . 47

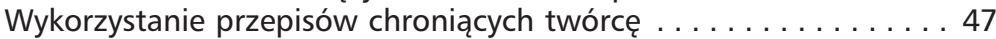

3.3 Przykładowe praktyczne rozwiązanie dla autora. . . . . . . . 49

4 Wdrażanie otwartego dostępu z perspektywy wydawnictwa . . . 552

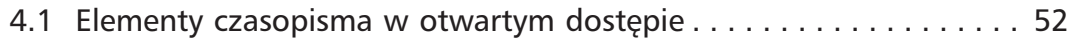

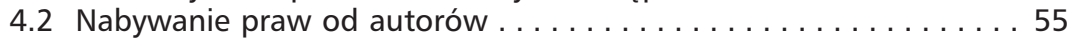

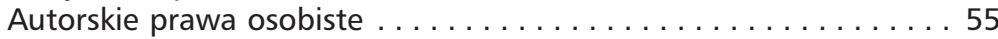

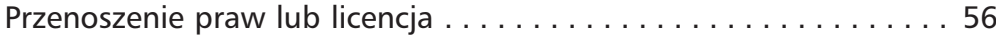

Specjalnie przygotowane umowy $\ldots \ldots \ldots \ldots \ldots \ldots \ldots \ldots \ldots$

Otwieranie archiwów. . . . . . . . . . . . . . . . . . 59

4.3 Przykładowe praktyczne rozwiązania dla wydawcy. . . . . . . 60

Wydawca naukowy finansowany publicznie . . . . . . . . . 60

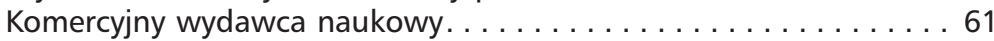

5 Wdrażanie otwartego dostępu z perspektywy jednostki

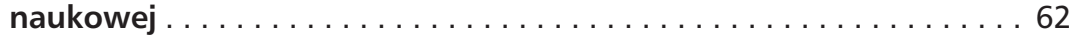

5.1 Otwarty mandat instytucji naukowej $\ldots \ldots \ldots \ldots \ldots \ldots \ldots \ldots 6$

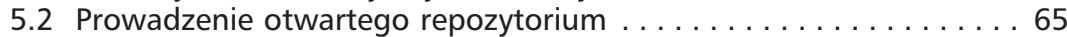

5.3 Przykładowe praktyczne rozwiązanie dla jednostki naukowej . . . 68

6 Wdrażanie otwartego dostępu z perspektywy instytucji

finansującej badania. . . . . . . . . . . . . . . 71

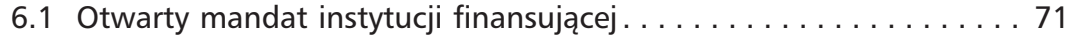

6.2 Wspieranie otwartego dostępu . . . . . . . . . . . . . 73

6.3 Przykładowe praktyczne rozwiązanie dla instytucji finansującej . . . 73

7 Aneks . . . . . . . . . . . . . . . 76

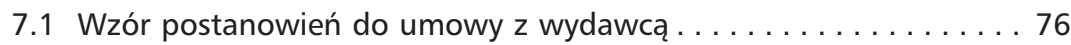

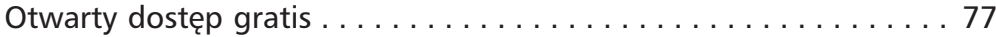

Otwarty dostęp libre . . . . . . . . . . . . . . . . . . 77

7.2 Wzór postanowień do regulaminu instytucji finansującej. . . . . . 78 


\section{Wprowadzenie}

Publikowanie jest nieodłącznym elementem działalności naukowej. Dla autorów jest podstawowym sposobem informowania o rezultatach ich pracy. Publikacje są analizowane i komentowane przez członków społeczności naukowej, dzięki czemu może nastąpić weryfikacja zawartych w nich twierdzeń. Stają się one ponadto źródłem inspiracji oraz podstawą dalszych badań, które owocują kolejnymi publikacjami. Publikacje naukowe są także źródłem wiedzy dla adeptów nauki, pozwalając na zasilanie szeregów badaczy przedstawicielami młodszych pokoleń.

Technologie informacyjno-komunikacyjne, a w szczególności Internet, otwierają nowe możliwości dla publikacji naukowych. Publikowanie w postaci cyfrowej pozwala na przyspieszenie i zintensyfikowanie procesów komunikacji, dyskusji, przekazywania wiedzy, komercjalizacji i innego wtórnego wykorzystywania publikacji naukowych. Środowisko cyfrowe nie jest jednak magiczną różdżka, a realizacja powyższych celów wymaga zapewnienia odpowiednich warunków. Chodzi przede wszystkim o dobór właściwych środków technicznych i organizacyjnych, gdyż sama „publikacja w Internecie” nie gwarantuje niczego. Technologie informacyjno-komunikacyjne stwarzają oczywiście nie tylko szanse, ale i zagrożenia.

Od kilkunastu lat, pośród różnych sposobów wykorzystywania technologii informacyjno-komunikacyjnych w kontekście publikacji naukowych, istotną rolę odgrywają modele otwartego dostępu (ang. open access). W największym skrócie, chodzi o umieszczanie publikacji naukowych w powszechnie dostępnym Internecie. Stopień 
ograniczeń towarzyszących tak udostępnionej publikacji stanowi kryterium wyróżnienia dwóch podstawowych modeli otwartego dostępu: (1) gratis i (2) libre. W pierwszym z nich osoba, której przysługują prawa autorskie do danej publikacji, godzi się jedynie na udostępnienie tej publikacji przez Internet. Zgodnie z ogólnymi zasadami prawa autorskiego oznacza to, że użytkownicy mogą z niej korzystać w bardzo ograniczonym zakresie. Drugi model jest szerszy: obejmuje udostępnienie utworu w Internecie oraz dodatkową zgodę uprawnionego na korzystanie $z$ niego przez każdego w bardzo szerokim zakresie.

$\mathrm{Z}$ prawnego punktu widzenia, wprowadzenie otwartego dostępu do publikacji naukowej jest możliwe po uzyskaniu zgody uprawnionego (licencji) na określony model otwartego dostępu. W praktyce, sama zgoda okazuje się często ostatnim etapem procesu udostępniania, poprzedzonym działaniami takimi jak: ustalenie, kto i w jakim zakresie jest uprawniony do rozpowszechniania danej pracy, analiza wcześniej zawartych umów, projektowanie modelu prawnego relacji uprawniony-udostępniający-użytkownicy, itd. Sprawne wdrażanie otwartego dostępu wymaga prawidłowego zarządzania kwestiami prawnymi na wszystkich tych etapach. Nie ma bowiem prawnych przeszkód, które uniemożliwiałyby otwarty dostęp, a jedynie kwestie wymagające określonych decyzji lub negocjacji wspartych wiedzą prawniczą. Napotykane wątpliwości można w praktyce rozwiązać na korzyść otwartego dostępu stosując odpowiednie narzędzia prawne.

Z obserwacji i doświadczeń autora wynika, że wśród naukowców, wydawców, a także jednostek naukowych oraz instytucji finansujących naukę istnieje istotne zapotrzebowanie na wyjaśnienia i rozwiązania kwestii prawnych napotykanych przy wdrażaniu otwartego dostępu. Naszym celem jest zaspokojenie tych potrzeb. Chcemy pokazać, że wdrażanie otwartego dostępu może być proste. Tam, gdzie jest to możliwe, przedstawiamy rozwiązania gotowe do wykorzystania. Prezentujemy również prawną argumentację rozwiewającą pewne przesądy dotyczące otwartego dostępu.

Na potrzeby analizy podzieliliśmy czytelników na przedstawicieli następujących grup: (1) autorów, (2) wydawców, (3) jednostek naukowych, (4) instytucji finansujących naukę. Podstawą takiego podziału jest to, że każda $z$ tych grup napotyka inne kwestie prawne lub zmaga 
się z nimi z innej perspektywy. Zanim jednak przejdziemy do poszczególnych części, dedykowanych każdej z tych grup, przedstawiamy część ogólną, poświęconą kwestiom wspólnym oraz podstawowym definicjom. Zachęcamy ponadto wszystkich czytelników do uważnej lektury całości, a nie tylko dedykowanych im części. Pozwoli im to zrozumieć punkt widzenia podmiotów, z którymi będą wchodzić $\mathrm{w}$ różne relacje podczas wdrażania otwartego dostępu.

Przykładowe postanowienia dokumentów związanych z otwartym dostępem przedstawiamy w Aneksie. 


\section{Część ogólna}

Niniejsza część zawiera podstawowe informacje o instytucjach prawa autorskiego istotnych z punktu widzenia wprowadzania otwartego dostępu do publikacji naukowych. Przedstawiamy tu także definicje kluczowych pojęć funkcjonujących w obszarze otwartego dostępu. Poza tym przedstawiamy w tym rozdziale wyjaśnienia niektórych kwestii prawnych, które są wspólne dla wszystkich grup czytelników zainteresowanych wprowadzaniem otwartego dostępu.

\subsection{Otwarty dostęp i otwarte mandaty}

\section{- Prawnicza definicja otwartego dostępu}

Otwarty dostęp bywa różnie rozumiany. Niektóre definicje kładą większy nacisk na nieodpłatność dostępu, podczas gdy inne akcentują przede wszystkim brak innych ograniczeń dostępności, takich jak prawo autorskie lub zabezpieczenia techniczne. Może to prowadzić do nieporozumień, których w dużej mierze można uniknąć poprzez wyraźne rozróżnienie otwartego dostępu gratis i otwartego dostępu libre. Powtórzmy, że w pierwszym przypadku chodzi o udostępnienie publikacji przez Internet każdemu bez ograniczeń technicznych, jednak bez zezwolenia na korzystanie szersze, niż wynika to z przepisów prawa autorskiego o dozwolonym użytku. Natomiast w drugim przypadku publikacja jest udostępniona wraz z dodatkową zgodą uprawnionego na korzystanie $z$ niej przez każdego w bardzo szerokim zakresie (na wolnej licencji, o których szerzej poniżej). Rozróżnienie 
pomiędzy otwartym dostępem gratis a otwartym dostępem libre pokazuje, że otwartość jest cechą stopniowalną, a wybór określonego stopnia otwartości jest decyzją o charakterze pozaprawnym.

W każdym przypadku, otwarty dostęp nie oznacza rezygnacji z praw autorskich, umieszczenia utworu $\mathrm{w}$ domenie publicznej. Zrzeczenie się praw nie jest zresztą możliwe w polskim systemie prawa autorskiego, a przeniesienie do domeny publicznej następuje jedynie w wyniku upływu czasu ochrony autorskich praw majątkowych. Otwarty dostęp bywa ponadto niekiedy mylony z samym rozpowszechnieniem (potocznie: opublikowaniem) utworu. Tymczasem, o otwartym dostępie (nawet w modelu gratis) można mówić dopiero wtedy, gdy utwór jest udostępniony w Internecie i to bez zabezpieczeń technicznych.

Istotne jest precyzyjne definiowanie otwartego dostępu, zwłaszcza wobec pojawiania się takich nieporozumien. W ekspertyzie przygotowanej przez ICM UW na zlecenie MNiSW (http://www.nauka.gov. pl/fileadmin/user_upload/Nauka/Polityka_naukowa_panstwa/Analizy_ raporty_statystyki/20120208_EKSPERTYZA_OA_ICM.pdf) zaproponowano definicje otwartego dostępu gratis i libre sformułowane językiem prawniczym, zaczerpniętym głównie z przepisów prawa autorskiego. Takie prawnicze ujęcie ułatwia korzystanie z pojęcia otwartego dostępu w dokumentach prawnych takich jak umowy, a w przyszłości być może i ustawy. Definicje te brzmią następująco:

a (otwarty dostęp gratis) „darmowy i otwarty dostęp - rozpowszechnianie utworu lub przedmiotu prawa pokrewnego w taki sposób, aby każdy mógt mieć do nich dostęp $w$ miejscu $i w$ czasie przez siebie wybranym oraz możliwość nieodpłatnego i nieograniczonego technicznie korzystania $z$ nich zgodnie $z$ wtaściwymi przepisami o dozwolonym użytku lub $o$ innych wyjątkach przewidzianych $w$ przepisach prawa"

b (otwarty dostęp libre) „wolny $i$ otwarty dostęp - rozpowszechnianie utworu lub przedmiotu prawa pokrewnego w taki sposób, aby każdy mógt mieć do nich dostęp $w$ miejscu $i$ w czasie przez siebie wybranym wraz $z$ udzieleniem każdemu licencji na nieograniczone, nieodplatne i niewytaczne korzystanie $z$ nich oraz $z$ ich ewentualnych opracowań; licencja może zawierać postanowienia nakładajace na korzystajacego zobowiązania nienaruszajace istoty uprawnienia do nieograniczonego, nieodpłatnego 
i niewytacznego korzystania, takie jak obowiazek przekazania odbiorcy informacji o twórcy, producencie lub wydawcy, przedmiocie licencji oraz o jej postanowieniach, lub obowiazek udostępnienia odbiorcom przedmiotu licencji lub jego opracowania na takiej samej licencji".

Będziemy tu posługiwali się pojęciami "otwarty dostęp gratis" oraz „otwarty dostęp libre” zgodnie z powyższymi definicjami.

\section{- Otwarty mandat}

Otwartym mandatem nazywamy prawne zobowiązanie autorów prac naukowych do publikowania tych prac w otwartym dostępie. Łacińskie słowo „mandat” nie jest tu użyte w jego zwykłym znaczeniu, jakie funkcjonuje w języku polskim, gdzie oznacza zwykle „karę” (np. za przekroczenie prędkości) lub „upoważnienie” (np. mandat wyborczy). Wyrażenie „otwarty mandat” jest natomiast kalką językową wyrażenia angielskiego „open-access mandate”. Słowo „mandate” jest tam używane w znaczeniu „nakazu” lub „zobowiązania”. Sformułowanie „otwarty mandat” funkcjonuje jednak dość powszechnie w praktyce i stąd zdecydowaliśmy się go używać.

Abstrahując od konkretnego porządku prawnego, zobowiązanie do publikowania prac naukowych w otwartym dostępie może na autorów nałożyć pracodawca (jednostka naukowa), instytucja finansująca badania naukowe, albo ustawodawca. Tutaj zajmujemy się otwartymi mandatami jednostek naukowych (rozdział 5) oraz instytucji finansujących (rozdział 6). Nie omawiamy natomiast ustawowych otwartych mandatów, gdyż analizujemy obecnie istniejący stan prawny, a prawo nie przewiduje obecnie takich mandatów (propozycje ich wprowadzenia znajdują się natomiast w przywołanej już ekspertyzie ICM dla MNiSW).

W modelu gratis, otwarty mandat zobowiązuje autorów do udostępniania publikacji w Internecie bez zabezpieczeń technicznych. W modelu libre, otwarty mandat zobowiązuje ich ponadto do udzielania wolnych licencji do udostępnianych publikacji. Otwarty mandat powinien być elementem szerszej polityki otwartego dostępu danej jednostki, w ramach której jednostka uwzględni szereg uwarunkowań. 


\subsection{Zakres swobody użytkownika}

Podstawowe różnice pomiędzy otwartym dostępem gratis a otwartym dostępem libre sprowadzają się do zakresu swobód użytkowników udostępnianych publikacji.

\section{- Swobody użytkownika w otwartym dostępie gratis}

Umieszczenie publikacji w otwartym dostępie gratis nie powoduje, że jej użytkownicy uzyskują jakiekolwiek uprawnienia do wkroczenia w zakres wyłączności gwarantowany twórcy (lub innemu uprawnionemu) przez prawo autorskie. O ile nie uzyskają od takiej osoby dodatkowej licencji, mogą korzystać z utworu wyłącznie w zakresie nieobjętym monopolem autorskim. W praktyce oznacza to dla nich konieczność działania zgodnie z przepisami o dozwolonym użytku.

Dozwolony użytek dzieli się na użytek prywatny i publiczny. W dużym uproszczeniu, użytek prywatny oznacza możliwość zwielokrotniania utworów na potrzeby własne osób fizycznych oraz osób $z$ ich kręgu rodzinnego i towarzyskiego. Dokładny zakres dozwolonego użytku prywatnego jest wciąż przedmiotem kontrowersji i dyskusji wśród prawników. Na pewno jednak nie jest dozwolone publiczne rozpowszechnianie oryginałów ani opracowań publikacji udostępnionych $\mathrm{w}$ otwartym dostępie gratis.

Natomiast dozwolony użytek publiczny obejmuje działania takie jak: cytowanie, przedruk, udostępnianie przez biblioteki, szkoły i archiwa, zwielokrotnianie utworów w celach edukacyjnych i naukowych oraz kilka innych możliwości wskazanych w ustawie. W odróżnieniu od dozwolonego użytku prywatnego, dozwolony użytek publiczny umożliwia publiczne rozpowszechnianie utworów lub ich części, jest to jednak obwarowane szeregiem wymogów. Szczegółowy zakres tych wymogów zależy od konkretnej postaci dozwolonego użytku - korzystanie z tej instytucji prawnej musi zawsze mieścić się $\mathrm{w}$ ramach konkretnego przepisu.

Niektóre przepisy znajdujące się w rozdziale ustawy o prawie autorskim i prawach pokrewnych poświęconym dozwolonemu użytkowi są właściwie licencją ustawową, gdyż przyznają uprawnionemu wynagrodzenie $z$ tytułu ustawowo dozwolonego wykorzystania 
utworu. Użytkownik nie musi wtedy pytać o zgodę na wykorzystanie utworu w określony sposób, musi natomiast zapłacić za to wykorzystanie. Co do zasady jednak, korzystanie z utworów w ramach dozwolonego użytku nie wymaga ani zgody uprawnionego, ani zapłaty mu wynagrodzenia bezpośrednio. Prawo autorskie wprowadza natomiast pośrednią odpłatność dozwolonego użytku prywatnego, w postaci opłat ukrytych w cenach nośników, takich jak papier ksero i kserokopiarki, dyski twarde, czyste nośniki itd. Opłaty te są pobierane przez organizacje zbiorowego zarządzania i powinny trafiać do twórców, nawet jeżeli ich publikacje zostały udostępnione w otwartym dostępie. Jest tak dlatego, że wynagrodzenia finansowane $z$ tych opłat zostały określone w ustawie jako niezbywalne.

Podsumowując, udostępnienie publikacji naukowej w otwartym dostępie gratis usuwa tylko podstawowe ograniczenia w korzystaniu z publikacji. Użytkownik może ją pobrać i nieodpłatnie wykorzystywać do własnych potrzeb. Może być ona cytowana, a niekiedy nawet przedrukowywana lub w inny sposób w całości udostępniana, np. studentom i uczniom. Każde takie działanie musi jednak znaleźć podstawę w postaci konkretnego przepisu o dozwolonym użytku i spełnić wszystkie wskazane tam wymagania. W poszczególnych przypadkach mogą pojawić się wątpliwości, a to na użytkowniku spoczywa ciężar wykazania, że jego działanie mieści się w granicach dozwolonego użytku. Uprawnieni, którzy chcą rozwiać te wątpliwości lub od razu umożliwić szersze wykorzystywanie utworu, powinni albo rozważyć otwarty dostęp libre, albo przynajmniej złożyć dodatkowe oświadczenie dopuszczające określone sposoby wykorzystania.

\section{- Swobody użytkownika w otwartym dostępie libre}

Otwarty dostęp libre to otwarty dostęp gratis wraz z dodatkowym zezwoleniem uprawnionego (uprawnionych) na korzystanie z utworu poza zakresem dozwolonego użytku. Nie wystarcza jednak jakiekolwiek dodatkowe zezwolenie, aby można było uznać, że mamy już do czynienia z otwartym dostępem libre. Pojęcie „libre” odnosi się tutaj do wolności użytkownika, który zyskuje szerokie możliwości wykorzystywania udostępnianej publikacji naukowej. 
W pewnym uproszczeniu, wolność oznacza tu możliwość czynienia $z$ utworem tego wszystkiego, co może $z$ nim czynić podmiot autorskich praw majątkowych (i odnosi się to odpowiednio do praw pokrewnych). Jeżeli zgoda uprawnionego nie daje użytkownikowi tak szerokich możliwości, to bardzo możliwe, że mamy do czynienia $z$ otwartym dostępem szerszym niż otwarty dostęp gratis, ale nadal nie jest to otwarty dostęp libre.

\subsection{Wolne licencje}

Otwarty dostęp libre obejmuje tylko takie publikacje, które udostępniane są wraz z zezwoleniem na nieograniczone, nieodpłatne i niewyłączne korzystanie $z$ nich oraz $z$ ich ewentualnych opracowań (pełne wtórne wykorzystanie). Tak szerokie zezwolenia przyjęło się nazywać wolnymi licencjami. Wolna licencja może oczywiście zawierać pewne ograniczenia, które jednak nie mogą naruszać istoty wolności użytkownika. Dopuszczalne ograniczenia to:

a obowiązek przekazywania odbiorcom informacji o twórcy, producencie lub wydawcy, źródle, przedmiocie licencji oraz jej postanowieniach, określany jako „klauzula uznania autorstwa”,

b zakaz ograniczania swobody innych użytkowników, niekiedy połączony z obowiązkiem udostępniania przedmiotu licencji lub jego opracowań na takiej samej licencji, określany jako „klauzula copyleft” lub „klauzula share-alike”.

W praktyce, do udostępniania utworów na wolnych licencjach najczęściej używane są gotowe, standardowe wzorce umowne. Poszczególni uprawnieni nie tworzą własnych projektów umów, lecz udostępniają swoje utwory korzystając z ogólnie dostępnych wzorców wolnych licencji.

\section{- Licencje Creative Commons}

W odniesieniu do utworów innych niż programy komputerowe (w tym w odniesieniu do publikacji naukowych) największą popularnością cieszą się wzory licencji przygotowanych przez organizację Creative Commons (CC). CC udostępnia każdemu do nieodpłatnego wykorzystania sześć 
wzorców licencji. Wzorce te wyznaczają sześć punktów pośrednich pomiędzy domeną publiczną a zastrzeżeniem pełni praw autorskich.

Wzorce licencji CC powstały na wspólnej bazie ogólnych postanowień licencyjnych, które zawierają zezwolenie na bardzo szerokie wykorzystanie oryginału oraz opracowań utworów i przedmiotów praw pokrewnych stanowiących przedmiot licencji. Każda licencja CC jest nieodpłatna i niewyłączna, udzielana każdemu zainteresowanemu bez ograniczeń czasowych ani terytorialnych, i obejmuje wszystkie znane pola eksploatacji. Szerokiemu zakresowi uprawnień licencjobiorcy towarzyszy szerokie wyłączenie odpowiedzialności licencjodawcy.

\section{- Klauzule licencji CC}

Każdy z sześciu wzorców licencji CC zawiera inny zakres ograniczeń wolności użytkownika. Ograniczeniem występującym w nich wszystkich jest klauzula uznania autorstwa (klauzula BY), nakładająca na licencjobiorcę obowiązek przekazywania odbiorcom utworu określonych informacji o twórcy (licencjodawcy), źródle oraz licencji. Możliwe są też inne ograniczenia, które w poszczególnych wzorcach występują w różnych kombinacjach:

a klauzula „na tych samych warunkach” (ang. share-alike, w skrócie SA, w innych wolnych licencjach zwana "klauzulą copyleft”), czyli wymóg, aby licencjobiorca rozpowszechniający opracowanie licencjonowanego utworu udzielał do niego licencji takiej samej, jak licencja oryginału;

b klauzula użytku niekomercyjnego (ang. non-commercial, w skrócie NC), czyli zakaz komercyjnego korzystania $z$ licencjonowanego utworu (licencje CC pozbawione tej klauzuli pozwalają zarówno na niekomercyjne, jak i komercyjne korzystanie $z$ utworu);

c klauzula „bez utworów zależnych” (ang. no derivatives, w skrócie ND), czyli zakaz korzystania i rozporządzania opracowaniami utworów (licencjodawca pozostawia sobie możliwość decydowania o dopuszczaniu do obrotu np. tłumaczeń utworu).

Szczegółowy zakres poszczególnych klauzul wynika z tekstu prawnego licencji, czyli postanowień wyrażonych językiem prawniczym. 
To tekst prawny określa treść stosunku prawnego, jaki zawiązuje się pomiędzy licencjodawcą a licencjobiorcą $\mathrm{w}$ przypadku rozpowszechnienia utworu na podstawie licencji CC. Teksty prawne wszystkich sześciu wzorców CC dostępne są na stronach internetowych tej organizacji, pod adresem http://www.creativecommons.org/licenses/.

\section{- Wolne i nie-wolne licencje CC}

Liczba sześciu wzorców CC wynika z tego, że klauzula BY obecna jest w każdym z nich, a klauzule ND i SA wzajemnie się wykluczają. Przy takich założeniach, wszystkie możliwe kombinacje 4 klauzul tworzą 6 wzorców CC, które prezentujemy poniżej, uszeregowane od najbardziej liberalnego (wolnego) do najbardziej restrykcyjnego:
a CC-BY;
b CC-BY-SA;
c CC-BY-ND;
d CC-BY-NC;
e CC-BY-NC-SA;
f CC-BY-NC-ND.

W zależności od przyjmowanych założeń można oczywiście dyskutować nad kolejnością punktów w ramach następujących par: (a) i (b), (c) i (d) oraz (e) i (f). Niezależnie jednak od kolejności przyjętej w poszczególnych parach, tylko dwie pierwsze licencje można uznać za wolne: CC-BY oraz CC-BY-SA. Pozostałe wzorce zawierają zakaz korzystania komercyjnego lub zakaz korzystania z opracowań utworu, czyli ograniczenia swobód użytkownika, które są sprzeczne $z$ rozumieniem otwartego dostępu libre. Ale udostępnienie publikacji naukowej na licencji wskazanej w punktach (c), (d), (e) lub (f) będzie się mieściło $\mathrm{w}$ modelu otwartego dostępu gratis lub nawet wykraczało poza ten model.

Udzielenie wolnej licencji CC oznacza, że w zasadzie każdy może skorzystać z utworu w dowolnym miejscu i czasie, w dowolny sposób, bez konieczności bezpośredniego płacenia licencjodawcy za korzystanie. Ale nie oznacza to, że licencjodawca traci wszelkie możliwości uzyskiwania przychodu. Licencjodawca, który jest twórca, ma ustawowo zagwarantowane wynagrodzenia niezbywalne, płatne za 
pośrednictwem organizacji zbiorowego zarządzania prawami autorskimi. Ponadto, udostępnieniu utworu na nieodpłatnej wolnej licencji mogą towarzyszyć działania odpłatne, takie jak sprzedaż egzemplarzy lub odpłatne świadczenie usług. Wolne licencje utrudniają jedynie bezpośrednie zarabianie na utworze i $z$ tego punktu widzenia nie są rozwiązaniem dla osób, które oczekują wynagrodzenia za każde korzystanie $z$ utworu.

Jeżeli uprawniony zdecyduje się udostępnić swój utwór na licencji CC, to w zasadzie nie ma on już wpływu na to, kto stanie się licencjobiorcą. Zarówno wolne, jak i nie-wolne licencje CC są udzielane każdemu zainteresowanemu, a przekazanie przez licencjobiorcę utworu kolejnemu użytkownikowi czyni z tego użytkownika kolejnego licencjobiorcę (w sensie prawnym licencjobiorca jest posłańcem, dostarczającym treść licencji kolejnym jej stronom, jeżeli oczywiście wywiązuje się z obowiązków nałożonych klauzulą BY). Oznacza to na przykład, że utwór udostępniony na licencji CC w określonym repozytorium internetowym może zostać legalnie skopiowany w inne miejsce. Zakres tego rozprzestrzeniania można tylko częściowo ograniczać za pomocą nie-wolnych licencji CC zawierających klauzulę NC - wtedy legalne skopiowanie będzie możliwe tylko do niekomercyjnych serwisów.

W każdym przypadku licencjodawca musi podjąć przemyślaną decyzję co do wyboru licencji CC i zdawać sobie sprawę z konsekwencji tej decyzji. Wycofanie z obrotu utworu, który już został rozpowszechniony na licencji CC, może być bardzo trudne lub nawet niemożliwe, choć $z$ formalno-prawnego punktu widzenia licencję taką można wypowiedzieć.

\section{- Aktualizacje licencji CC}

Wzorce licencji CC są od czasu do czasu aktualizowane. W chwili obecnej najbardziej aktualne są wersje 3.0, trwają jednak prace nad wersją 4.0, która ma wprowadzić różne -- obecnie publicznie dyskutowane -- zmiany. Ogólne założenia pozostają jednak niezmienione.

Udzielenie licencji to czynność prawna, do której dochodzi pomiędzy licencjodawcą a indywidualnym użytkownikiem, w oparciu o kon- 
kretny wzorzec licencji CC wybrany przez licencjodawcę. Organizacja Creative Commons nie jest stroną licencji udzielanych za pomocą publikowanych przez nią wzorców. Między innymi dlatego późniejsze opublikowanie nowej wersji licencji przez CC nie powoduje żadnych zmian stosunków prawnych pomiędzy osobami, które wybrały wcześniejszą wersję. Co więcej, jeżeli licencjodawca w sposób wyraźny nie zmieni używanego przez siebie wzorca na nowy, kolejne umowy będą zawierane według starego wzorca.

Podmioty wdrażające otwarty dostęp powinny brać pod uwagę zjawisko aktualizowania licencji i zapewnić sobie możliwość przechodzenia na nowe wersje licencji, kiedy tylko uznają to za pożądane. Jest to możliwe, jeżeli zostanie wyraźnie zaznaczone w treści umów zawieranych $z$ uprawnionymi.

\section{- Krajowe wersje licencji CC}

Partnerzy Creative Commons działający w poszczególnych krajach przygotowują krajowe wersje wszystkich 6 wzorców. Wersje krajowe są dostosowane do specyfiki prawa danego kraju, podczas gdy wersje podstawowe (tzw. Unported) pisane są językiem międzynarodowych traktatów z zakresu prawa autorskiego i praw pokrewnych, co w założeniu ma umożliwić ich stosowanie niezależnie od jurysdykcji. Oznacza to, że uprawniony może wybierać nie tylko spośród 6 podstawowych wzorców, lecz ze znacznie większej liczby wersji krajowych, gdy zależy mu na lepszym uwzględnieniu specyfiki narodowego prawa. Wybór wersji krajowej nie oznacza jednak wyboru krajowego prawa. Dlatego też korzystanie z wersji krajowych ma największy sens w projektach otwartego dostępu o zasięgu niewykraczającym poza granice jednego kraju.

W praktyce trudno zawczasu przewidzieć, czy dla danego projektu bardziej właściwe będą wersje krajowe czy „międzynarodowe” (Unported). W związku z tym warto zadbać, aby umowa $z$ uprawnionym pozwalała na swobodny wybór wersji podmiotowi wdrażającemu otwarty dostęp, albo żeby przewidywała możliwość tzw. „podwójnego (wielokrotnego) licencjonowania”. Wielokrotne licencjonowanie oznacza udostępnienie utworu wraz z oświadczeniem, że użytkownik może 
wybrać jeden z kilku wskazanych wzorców licencji - jest to praktyka dość powszechna w obrocie wolnym oprogramowaniem (udostępnienie na licencjach GPL i np. MPL, bądź udostępnienie na licencji GPL i specjalnie przygotowanej licencji „komercyjnej”).

\section{- Zakres przedmiotowy licencji CC}

Licencje CC obejmują tylko utwory i przedmioty praw pokrewnych, a od wersji 3.0 także bazy danych chronione prawem sui generis. Co istotne, wszelkie zobowiązania wynikające $z$ poszczególnych klauzul licencji dotyczą tylko utworów i przedmiotów praw pokrewnych. W odniesieniu do chronionej prawem sui generis bazy danych, udzielenie licencji CC powoduje zrzeczenie się tego prawa, a na wypadek nieskuteczności zrzeczenia się - udzielenie bezwarunkowego zezwolenia na pobieranie danych i ich wtórne wykorzystanie.

Wolne licencje nie obejmują natomiast innych dóbr niematerialnych, jakie też mogą znaleźć się $\mathrm{w}$ publikacji - zawarte $\mathrm{w}$ nich zezwolenie nie rozciąga się zatem na te dobra. Dla przykładu, udostępnienie na licencji CC publikacji zawierającej opis opatentowanego wynalazku lub przedstawiającej zarejestrowane znaki towarowe nie oznacza samo $\mathrm{w}$ sobie zezwolenia na korzystanie $z$ nich $\mathrm{w}$ zakresie określonym w licencji. Podobnie, licencja CC nie pozwala na korzystanie $z$ towarzyszących publikacji dóbr osobistych, jak np. wizerunek autora. Można jedynie ostrożnie argumentować, że takie dodatkowe zezwolenie może wynikać z okoliczności konkretnej sytuacji. Co do zasady jednak, licencje CC nie obejmują tego typu dodatkowych przedmiotów praw.

Ponadto, licencjodawca może skutecznie udzielić licencji tylko na korzystanie z przedmiotów tych praw, które mu przysługują. Wiąże się to $z$ koniecznością ustalenia, jakie dokładnie przedmioty praw zawarte są w publikacji, jakie są podmioty tych praw (kto jest uprawniony do czego i w jakim zakresie), a następnie $z$ koniecznością zawarcia $z$ tymi podmiotami umów pozwalających na udostępnienie całości publikacji na licencji CC; kwestie te omawiamy szerzej w dalszej części. 


\section{- Sposób udzielenia licencji CC}

Udzielenie wolnej licencji do utworu, tak jak udzielenie każdej innej licencji niewyłącznej, nie wymaga żadnej szczególnej formy. Nie ma potrzeby podpisywania żadnych dokumentów. Wystarczy, jeżeli uprawniony w sposób wyraźny da do zrozumienia, że utwór jest udostępniony na konkretnej licencji CC. Ważne, aby wskazać dokładnie, o którą licencję CC chodzi, wraz z określeniem numeru jej wersji oraz tego, czy chodzi o wariant krajowy (np. PL), czy „międzynarodowy" (Unported). Poza opisem wybranej licencji, warto zamieścić przy utworze bezpośredni link do tekstu prawnego licencji znajdującego się na stronach creativecommons.org. Oznaczenie powinno być na tyle powiązane $z$ utworem (jego poszczególnymi egzemplarzami), aby $z$ technicznego punktu widzenia nie mogło zostać łatwo zagubione. Licencjodawca powinien też wyraźnie wskazać, jakie informacje o nim oraz twórcy mają być przekazywane użytkownikom na podstawie klauzuli uznania autorstwa (BY).

Powtórzmy, że papierowa dokumentacja i kolekcjonowanie własnoręcznych podpisów nie są prawnie wymagane dla zorganizowania otwartego dostępu do publikacji naukowych. Forma pisemna będzie konieczna jedynie wtedy, gdy strony zdecydują się na umowę przenoszącą autorskie prawa majątkowe lub licencję wyłączną (bez własnoręcznego podpisu umowy takie będą nieważne - art. 53 pr. aut. oraz art. 67 ust. 5 pr. aut.). Niemniej jednak podpisywanie dokumentów może być przydatne także $w$ innych okolicznościach, gdy stronom zależy na większej pewności dowodowej. Istotnie, wszyscy parający się obrotem dóbr chronionych prawem autorskim, w tym osoby wdrażające otwarty dostęp do publikacji naukowych, powinni móc udowodnić, czy i jakie uprawnienia do tych dóbr uzyskali. Własnoręczny podpis uprawnionego na papierowym dokumencie jest wciąż tradycyjnie uważany za mocny dowód, choć w określonych przypadkach wystarczające może być odpowiednie zorganizowanie procesu udzielania licencji od strony technicznej. Przykładowo, administrator otwartego repozytorium publikacji naukowych może zadbać o takie jego zaprojektowanie, aby umożliwić użytkownikom składanie oświadczeń o udzieleniu licencji za pomocą ich kont $\mathrm{w}$ serwisie (jest to zresztą 
standardowa praktyka wielu serwisów internetowych). Odpowiednio zabezpieczone zapisy elektroniczne tych oświadczeń będą wystarczającym dowodem ich złożenia.

\subsection{Prawna ochrona publikacji naukowych}

„Publikacja naukowa” to ogólne pojęcie, które może obejmować wiele kategorii prawnie chronionych dóbr niematerialnych. W grę może wchodzić ochrona wynikająca z prawa autorskiego (utwory, przedmioty praw pokrewnych), prawa własności przemysłowej (np. wynalazki opisane w publikacji), przepisów o bazach danych, czy też przepisów prawa cywilnego o dobrach osobistych, takich jak twórczość lub działalność naukowa.

Skupiamy się tu na zagadnieniach związanych z prawem autorskim, co oznacza, że przedmiotem naszego zainteresowania są publikacje naukowe stanowiące lub zawierające utwory lub przedmioty praw pokrewnych. Poniżej prezentujemy jednak podstawowe informacje o wszystkich wskazanych wyżej przedmiotach praw.

\section{- Utwory}

Utworem jest „każdy przejaw działalności twórczej o indywidualnym charakterze, ustalony $\mathrm{w}$ jakiejkolwiek postaci, niezależnie od wartości, przeznaczenia i sposobu wyrażenia" (art. 1 ust. 1 pr. aut.). Powszechnie przyjmuje się dość niski próg indywidualnej twórczości wymagany do uznania danego wytworu intelektu za „utwór”. Zatem prawdopodobieństwo, że dana publikacja naukowa jest utworem, jest w większości przypadków bardzo wysokie. Podobnie, istnieje wysokie prawdopodobieństwo, że utworami są również cudze materiały wykorzystane do przygotowania publikacji lub w niej zamieszczone.

\section{- Programy komputerowe}

Prawo autorskie chroni programy komputerowe w szczególny sposób. $\mathrm{Z}$ punktu widzenia wdrażania otwartego dostępu do publikacji naukowych, chodzi tu zwłaszcza o wyłączenie ogólnych zasad dotyczących 
utworów pracowniczych oraz pracowniczych utworów naukowych (o czym dalej). Ma to istotny wpływ na ustalenie podmiotu praw. Programy komputerowe nie podlegają także większości przepisów o dozwolonym użytku, co znacznie ogranicza możliwości korzystania $z$ nich bez zgody uprawnionego.

Rzadko zdarza się, żeby program komputerowy sam w sobie stanowił publikację naukową. Program może raczej stanowić podstawę publikacji naukowej, w której znajduje się jego opis lub analiza, lub w której zostanie zacytowany fragment jego kodu źródłowego.

\section{- Przedmioty praw pokrewnych}

Poza utworami, ustawa o prawie autorskim i prawach pokrewnych chroni wymienione tam przedmioty praw pokrewnych. Są to:

a artystyczne wykonania;

b fonogramy i wideogramy;

c nadania programów;

d pierwsze wydania oraz wydania naukowe i krytyczne niechronionych utworów.

Można z dużym prawdopodobieństwem założyć, że większość publikacji pisanych oraz wydawanych w sposób tradycyjny nie będzie zawierać przedmiotów praw pokrewnych, lecz tylko same utwory. Wyjątkiem będą pierwsze, naukowe lub krytyczne wydania niechronionych już utworów (czyli takich, które przeszły do domeny publicznej). Wtedy, choć sam utwór chroniony nie jest, należy liczyć się z prawem osoby, która przygotowała takie wydanie.

Połączenie chronionego utworu oraz przedmiotu praw pokrewnych będzie miało miejsce w przypadku publikacji innych niż pisane lub publikacji pisanych wydawanych w technikach multimedialnych. Dobrym przykładem są nagrania $z$ konferencji naukowych. Takie nagrania, poza samym referatem stanowiącym utwór, zawierać mogą również artystyczne wykonanie tego referatu (jakkolwiek dziwnie może to brzmieć), a ponadto będą stanowiły fonogram lub wideogram (w zależności od sposobu utrwalenia). W przypadku transmisji radiowej lub telewizyjnej konferencji powstanie dodatkowe prawo do nadania, przynależne organizacji radiowej lub telewizyjnej. 
Prawa pokrewne nie muszą należeć do tej samej osoby, co prawa autorskie, co może oznaczać konieczność kontaktowania się z wieloma podmiotami.

Dla przykładu, autor nie może samodzielnie dysponować nagraniem swojego wystąpienia na konferencji naukowej, gdyż prawa pokrewne do fonogramu/wideogramu należeć będą do jego producenta, którym najprawdopodobniej będzie organizator konferencji. $\mathrm{Z}$ kolei organizator nie może bez zgody referenta swobodnie dysponować takim nagraniem $z$ uwagi na zawarty $\mathrm{w}$ nim materiał chroniony prawami autorskimi referenta. Brak zgody pozwala organizatorowi na korzystanie $z$ tego nagrania wyłącznie $\mathrm{w}$ granicach dozwolonego użytku (np. art. 25 ust. 1 pkt 4 pr. aut. pozwala publikować bez zgody uprawnionego mowy wygłoszone na publicznych zebraniach i rozprawach).

\section{- Bazy danych}

Prawo autorskie nie chroni co prawda elementów nietwórczych (faktów, idei, zasad), uznaje jednak za utwory „zbiory, antologie, wybory, bazy danych ... o ile przyjęty w nich dobór, układ lub zestawienie ma twórczy charakter ... " (art. 3 pr. aut.). Innymi słowy, bazy danych mogą być chronione prawem autorskim, o ile zawierają wkład indywidualnej twórczości, przejawiający się na poziomie zebrania elementów bazy (niezależnie od ochrony mogącej ewentualnie przysługiwać samym elementom). Może to oznaczać, że utworem będą np. wyniki badań naukowych, jeżeli stanowią one uporządkowane w sposób twórczy informacje o faktach, nawet jeżeli same te informacje chronione nie będą.

Niezależnie od ochrony, jaka może przysługiwać bazom danych na podstawie prawa autorskiego, mogą one podlegać ustawie o ochronie baz danych (tzw. ochrona sui generis). W największym skrócie, przesłanką udzielenia ochrony sui generis jest poniesienie istotnego jakościowo lub ilościowego nakładu inwestycyjnego na sporządzenie, weryfikację lub prezentację zawartości bazy (art. 2 ust. 1 pkt 1 ubd). Zatem, bazy zawierające wkład twórczy oraz inwestycyjny są chronione zarówno przez prawo autorskie, jak i na podstawie tej ustawy. 
Nietwórcze lecz wymagające inwestycji bazy danych są chronione tylko prawami sui generis. Tylko wtedy, kiedy bazy nie charakteryzuje ani wkład twórczy, ani wkład inwestycyjny, jest ona wyłączona zarówno spod ochrony prawno-autorskiej, jak i spod ochrony sui generis.

W odniesieniu do otwartego dostępu do publikacji naukowych, ochrona baz danych może mieć znaczenie w dwóch przypadkach. Po pierwsze, może chodzić o umieszczenie w otwartym dostępie zbioru publikacji naukowych stanowiącego bazę danych (np. archiwum czasopisma naukowego). Po drugie, może chodzić o umieszczenie w otwartym dostępie publikacji naukowej zawierającej lub w inny sposób wykorzystującej bazę danych (np. tabele wyników badań).

\section{- Prawa własności przemysłowej}

Prawo własności przemysłowej przewiduje ochronę dla przedmiotów takich, jak np. wynalazki czy znaki towarowe, których opisy lub przedstawienia mogą znaleźć się w publikacji naukowej. Rodzi to pewne konsekwencje niezależnie od konsekwencji prawno-autorskich.

Dla przykładu, ujawnienie istoty wynalazku w publikacji w zasadzie uniemożliwi uzyskanie na niego patentu, gdyż jedną z przesłanek udzielenia patentu jest nowość wynalazku. Natomiast opis opatentowanego już wynalazku w publikacji udostępnionej w otwartym dostępie libre nie pozbawia go ochrony patentowej (prawidłowo przypisana do artykułu wolna licencja nie rozciąga się na opisany w nim wynalazek).

Kwestie te nie będą tu jednak rozwijane, gdyż skupiamy się na kwestiach regulowanych w prawie autorskim.

\section{- Dobra osobiste}

Dobra osobiste to pewne wartości związane ściśle z osobą człowieka lub jego działalnością. Ich ochrona to prawne poszanowanie i gwarancja ludzkiej osobowości i godności. Ochrona dóbr osobistych wynika z przepisów kodeksu cywilnego, art. 23 kc zawiera ich przykładową listę. Szczególne znaczenie w kontekście otwartego udostępniania publikacji naukowych mają następujące ze wskazanych tam dóbr oso- 
bistych: nazwisko lub pseudonim, wizerunek, tajemnica korespondencji, twórczość naukowa, artystyczna, wynalazcza i racjonalizatorska.

Ochrona dóbr osobistych przysługuje niezależnie od ochrony wynikającej z innych przepisów. Dla przykładu, twórca może żądać poszanowania jego twórczości niezależnie od tego, że jej poszczególne przejawy są chronione prawem autorskim. Ochrona dóbr osobistych nabiera jednak szczególnego znaczenia tam, gdzie nie sięga prawo autorskie. Dla przykładu, inspiracja, wykorzystanie cudzej idei $\mathrm{w}$ publikacji naukowej nie stanowi wkroczenia $\mathrm{w}$ prawa autorskie. Wskazane jest jednak wskazywanie źródła inspiracji i autorstwa cudzych idei wykorzystanych w publikacji. Oprócz pozaprawnych zasad rzetelności naukowej, źródłem tego obowiązku może być właśnie prawna ochrona dóbr osobistych - szeroko rozumianej twórczości. Granicą tego obowiązku jest oczywiście głównie zdrowy rozsądek, a w tym faktyczna możliwość przypisania określonych idei lub źródeł inspiracji konkretnym osobom.

Kwestie te jedynie sygnalizujemy. Uważamy, że w kontekście otwartego udostępniania publikacji naukowych nie pojawiają się żadne szczególne problemy związane z dobrami osobistymi, które różniłyby się istotnie od problemów występujących w kontekście ogólnym.

\subsection{Ustalenie uprawnionego}

Umieszczenie publikacji naukowej w otwartym dostępie jest formą rozpowszechnienia utworu (lub przedmiotu praw pokrewnych). Prawo stanowi, że jeżeli takie działanie stanowi wkroczenie w odpowiednie prawo wyłączne, to wymaga uzyskania zezwolenia od podmiotu uprawnionego (licencji). Granice prawa wyłącznego wyznaczają m.in. przepisy o dozwolonym użytku, jednak obecnie żaden z nich nie pozwala nikomu umieścić publikacji naukowej w Internecie bez zgody uprawnionych. Zatem, każdy podmiot wdrażający otwarty dostęp do publikacji naukowych musi uzyskać zgodę osób uprawnionych do tych publikacji.

W niektórych przypadkach mogą powstać wątpliwości, kto jest uprawniony do publikacji naukowej, względnie czy i jakie osoby trzecie mogą zgłaszać swoje ewentualne roszczenia w przypadku korzy- 
stania $z$ danej publikacji. Konieczne jest wobec tego takie wdrażanie otwartego dostępu, aby minimalizować te wątpliwości oraz wynikające z nich ryzyko prawne. Stosowne działania różnią się głównie W zależności od tego, jaką rolę pełni w całym procesie określony podmiot. W dużej mierze są to kwestie, jakie napotyka każdy uczestnik obrotu materiałami chronionymi prawem autorskim. W większości przypadków nie są one specyficzne dla zagadnienia otwartego dostępu. Nie zawsze też konieczne będzie analizowanie wszystkich niuansów. Poniżej przedstawiamy podstawowe informacje w tym zakresie.

\section{- Dualizm praw autorskich}

W polskim systemie prawa autorskiego prawa autorskie dzielą się na prawa osobiste i prawa majątkowe. Autorskie prawa osobiste są niezbywalne i chronią więź twórcy z utworem, przejawiającą się np. w oznaczaniu utworu własnym nazwiskiem, pseudonimem (lub publikacji anonimowej), decydowaniu o pierwszej publikacji, ochronie integralności dzieła i nadzoru nad sposobem jego wykorzystania (art. 16 pr. aut.). Autorskie prawa osobiste zawsze przysługują twórcy. Twórcą jest osoba fizyczna, która wniosła do utworu wkład indywidualnej twórczości. W uproszczeniu, twórcą będzie faktyczny autor publikacji, a nie np. osoba, która tylko dawała autorowi wskazówki, wytyczne, czy dostarczyła wyniki komentowanych badań. Osoby takie oczywiście mogą być (a niekiedy nawet powinny być) wskazywane w publikacji, ale jako autorzy odpowiednich wkładów, a nie jako współtwórcy publikacji.

Autorskie prawa majątkowe mają natomiast służyć ochronie interesów ekonomicznych uprawnionego. W największym skrócie, ochrona ta polega na przyznaniu uprawnionemu wyłączności w zakresie decydowania o tym, kto i jak może korzystać z jego utworu. Prawa te są zbywalne, co implikuje dwie kategorie podmiotów autorskich praw majątkowych: (1) podmioty pierwotne i (2) nabywcy pochodni. Podmiot pierwotny to taki, który wywodzi swoje uprawnienia bezpośrednio z przepisów ustawy, a nie od prawnego poprzednika. Źródłem praw nabywcy pochodnego jest natomiast stosunek prawny $z$ ich poprzednim podmiotem, taki jak na przykład umowa lub dziedziczenie.

Pierwotnym podmiotem autorskich praw majątkowych jest 
twórca, chyba że zachodzi wyjątek przewidziany w ustawie. Takimi wyjątkami są utwory zbiorowe (o których szerzej poniżej) oraz pracownicze programy komputerowe - w stosunku do tych utworów autorskie prawa majątkowe $z$ mocy ustawy przysługują pierwotnie podmiotowi finansującemu ich powstanie, tj. wydawcy, producentowi lub pracodawcy twórcy. Co istotne, pracodawca twórcy utworu pracowniczego innego niż program komputerowy nie jest pierwotnym podmiotem autorskich praw majątkowych, lecz ich pochodnym nabywcą. Podstawą tego nabycia jest umowa o pracę, z której wynika m. in. zakres nabytych praw.

Pierwotnemu podmiotowi autorskich praw majątkowych przysługuje wyłączność korzystania i rozporządzania utworem na wszelkie sposoby („na wszystkich polach eksploatacji” - art. 17 pr. aut.). Może on zbyć te prawa na wybraną przez siebie osobę w drodze umowy (prawa te są także dziedziczone). Zgodnie z polskim prawem do umownego zbycia dochodzi tylko na wskazanych przez strony umowy polach eksploatacji (art. 41 ust. 2 pr. aut. - tzw. „zasada specyfikacji pól eksploatacji”). Oznacza to, że nabywca pochodny praw może decydować (zakazywać lub zezwalać innym osobom) jedynie o takich sposobach korzystania $z$ utworu, jakie zostały opisane w umowie. Niemniej jednak, ustalenie, jakie pola zostały wskazane w umowie, następuje w drodze jej wykładni (m. in. badania okoliczności jej zawarcia i woli stron). Zasada specyfikacji pól eksploatacji jest poza tym złagodzona w przypadku umów o pracę (o czym poniżej). Można też oczekiwać, że w przypadku sporu, sąd będzie bardziej rygorystycznie stosował tę zasadę wtedy, gdy stroną umowy jest wymagający szczególnej ochrony twórca, a mniej, gdy umowę zawierają dwa profesjonalne podmioty (np. wydawca i dystrybutor). Ale nawet w takim przypadku trudno o przeniesienie „całości praw majątkowych” bez wskazywania pól eksploatacji, skoro zazwyczaj na początku każdego łańcucha umów przenoszących autorskie prawa majątkowe jest właśnie twórca.

\section{- Twórca jako podmiot praw autorskich}

Autor publikacji naukowej, czyli twórca, jest zawsze podmiotem autorskich praw osobistych do tej publikacji. Może, ale nie musi, być rów- 
nież podmiotem autorskich praw majątkowych (jest to stan domyślny wynikający $z$ art. 8 pr. aut., który może być zmodyfikowany przepisem szczególnym lub umowa).

Jeżeli autor ma zarówno autorskie prawa osobiste, jak i majątkowe, to udostępnienie publikacji naukowej w wybranym przez niego modelu otwartego dostępu zależy od jego samodzielnej decyzji. W praktyce prawa majątkowe często należą jednak do innych osób, w różnym zakresie.

\section{- Utwory pracownicze}

Istotnym wyjątkiem od zasady przysługiwania autorskich praw majątkowych twórcy są utwory pracownicze (wyjątkiem od tego wyjątku są natomiast pracownicze utwory naukowe, które omawiamy w następnym podrozdziale). Utwory pracownicze to utwory stworzone przez pracownika w wyniku wykonywania obowiązków wynikających ze stosunku pracy. Zgodnie $z$ art. 12 pr. aut., autorskie prawa majątkowe do takich utworów nabywa pracodawca, przy czym nabycie następuje $w$ granicach wynikających $z$ celu umowy o pracę i zgodnego zamiaru stron. Nie obowiązuje tu zatem ściśle zasada specyfikacji pól eksploatacji, ale wskazane jest wyraźne określenie tych granic i zamiaru, gdyż w przeciwnym wypadku powstaną wątpliwości co do zakresu nabycia. Poza tym, zgodnie z art. 12 pr. aut., nabycie praw jest uzależnione od tego, czy pracodawca przyjmie utwór pracowniczy.

Nabycie praw przez pracodawcę powoduje, że umieszczenie utworu $\mathrm{w}$ otwartym dostępie może wymagać jego zgody. Zależy to od zakresu nabytych praw oraz wybranego modelu otwartego dostępu. W praktyce może pojawić się wątpliwość co do zakresu praw przysługujących pracodawcy. Jeżeli umowa o pracę nie zawiera żadnych postanowień na ten temat, to zakres ten trzeba ustalać zgodnie $z$ art. 12 pr. aut. w oparciu o cel umowy i zgodny zamiar stron. Wątpliwe może być również to, czy utwór powstał w ramach wykonywania obowiązków pracowniczych, jeżeli zostały one określone w sposób zbyt lakoniczny. Utwory stworzone poza obowiązkami pracowniczymi nie podlegają regulacji art. 12 pr. aut. 


\section{- Pracownicze utwory naukowe}

Art. 12 pr. aut. nie obejmuje utworów naukowych tworzonych w ramach obowiązków pracowniczych przez pracowników instytucji naukowych. Utwory takie regulowane są szczególnym przepisem art. 14 pr. aut. Ustawa nie zawiera jednak definicji utworu naukowego ani instytucji naukowej, co może rodzić praktyczne problemy $\mathrm{z}$ ustaleniem, które przepisy należy stosować $\mathrm{w}$ określonej sytuacji. Zakładamy tu jednak, że wątpliwości co do naukowego statusu pracodawcy lub utworu będą dotyczyły sytuacji szczególnych. Uważamy zatem, że publikacja naukowa, prezentująca w sposób twórczy wyniki badań istniejącej obiektywnie rzeczywistości, prowadzonych według określonej naukowej metody, będzie utworem naukowym. W praktyce nie powinno być też zwykle większego problemu z ustaleniem, czy pracodawcą twórcy jest instytucja naukowa (działalność naukowa nie musi być zasadniczym celem jej istnienia).

Skutki art. 14 pr. aut. znacząco odbiegają od skutków art. 12 pr. aut. Instytucja naukowa nie nabywa autorskich praw majątkowych do pracowniczego utworu naukowego; przysługuje jej jedynie pierwszeństwo opublikowania go. W razie skorzystania $z$ tego pierwszeństwa, twórcy przysługuje prawo do wynagrodzenia (poza wynagrodzeniem z umowy o pracę). Szczegóły zależą od postanowień umowy o pracę lub umowy dotyczącej wydania konkretnego utworu - umowy te mogą zresztą całkowicie zmodyfikować zasadę wynikającą $z$ art. 14 ust. 1 pr. aut.

Przy braku wyraźnych uregulowań w takiej umowie, można mieć wątpliwości głównie co do dokładnego zakresu pierwszeństwa instytucji naukowej. Art. 14 ust. 1 pr. aut. posługuje się mianowicie sformułowaniem „pierwszeństwo opublikowania”. Definicja utworu opublikowanego zawarta jest natomiast $\mathrm{w}$ art. 6 ust. 1 pkt 1 pr. aut., który brzmi: „utworem opublikowanym jest utwór, który za zezwoleniem twórcy został zwielokrotniony i którego egzemplarze zostały udostępnione publicznie”. $Z$ egzemplarzem utworu mamy do czynienia jedynie w przypadku jego utrwalenia na materialnym nośniku, a panuje dość rozpowszechniony pogląd, że umieszczenie utworu „W Internecie" nie prowadzi rzekomo do takiego utrwalenia. 
Naszym zdaniem, „w Internecie” istotnie nie dochodzi do obrotu egzemplarzami utworów, lecz do ich zwielokrotniania (kopiowania z komputera na komputer). Jednak trudno uznać, że utwór zapisany na serwerze, udostępniającym go każdemu do takiego skopiowania, nie został utrwalony na materialnym nośniku ani że ten egzemplarz nie jest udostępniony publicznie (choć jest to dostęp zdalny). Uważamy zatem, że umieszczenie pracowniczego utworu naukowego w otwartym dostępie gratis mieści się w przysługującym instytucji naukowej pierwszeństwie. Niemniej jednak, stosując kwestionowane tu rozumowanie można twierdzić, że pierwszeństwo opublikowania w art. 14 ust. 1 pr. aut. nie obejmuje udostępnienia w Internecie, lecz jedynie wydanie w bardziej tradycyjnej formie (np. druk).

Co istotne, rekomendowane tu sposoby wdrożenia otwartego dostępu poprzez otwarte mandaty (patrz zwłaszcza rozdział 46) można stosować w dużej mierze niezależnie od interpretacji zakresu pierwszeństwa art. 14 pr. aut. Podstawą tych otwartych mandatów może być zresztą zarówno art. 14, jak i 12 pr. aut., choć oczywiście wpłynie to na kształt prawny wdrożenia (np. postanowienia dokumentów powinny uwzględniać różne możliwe stany faktyczne). Ustalenie, czy konkretny utwór objęty jest regulacją art. 12 czy 14 pr. aut., ma natomiast większe znaczenie w sytuacji, gdy pracodawca nie zamierza udostępniać utworów pracowniczych w otwartym dostępie, a taką wolę wykazują ich autorzy.

\section{- Pracownicze programy komputerowe i bazy danych}

Art. 12 i 14 pr. aut. nie dotyczą w ogóle programów komputerowych, nawet jeżeli programowi można by przypisać cechy „utworu naukowego". Prawa do programu stworzonego w ramach obowiązków pracowniczych w całości i z mocy ustawy przysługują pracodawcy (art. 74 ust. 3 pr. aut.).

Podobna sytuacja ma miejsce w przypadku baz danych. W zakresie, $\mathrm{w}$ jakim podlegają one ochronie prawa autorskiego, stanowić będą utwory zbiorowe, do których prawa z mocy ustawy przysługują producentowi lub wydawcy (szerzej o utworach zbiorowych poniżej). Także prawa sui generis do baz danych przysługują z mocy ustawy pro- 
ducentowi, a nie zatrudnionym przez niego pracownikom lub innym osobom.

Nie będziemy się jednak tu odnosić do programów komputerowych ani baz danych, które same stanowią publikacje naukowe. Dobrym przykładem takich programów i baz są słowniki elektroniczne. Mając świadomość ich istotnego znaczenia, ograniczamy się tu do programów i baz stanowiących podstawę publikacji lub wykorzystywanych $\mathrm{w}$ tych publikacjach (np. cytowanie, opis). Kwestie te analizujemy szerzej w podrozdziale 2.6.

\section{- Utwory współautorskie}

Często autor nie jest jedynym twórcą publikacji naukowej. Jeżeli kilka działających $\mathrm{w}$ porozumieniu osób wniosło do utworu swoje twórcze wkłady, tak że tworzą one jedno dzieło, wszystkie te osoby są współtwórcami utworu (art. 9 pr. aut.). Współtwórcom przysługują wspólne autorskie prawa majątkowe (domniemywa się, że udziały w tych prawach są równe). Oznacza to, że dysponowanie utworem, $\mathrm{w}$ tym umieszczenie go w otwartym dostępie, wymaga jednomyślności wszystkich współtwórców.

Pojedynczy współtwórca może samodzielnie dysponować jedynie swoją częścią, mającą samodzielne znaczenie, o ile nie stanowi to uszczerbku dla praw pozostałych współtwórców, przy czym omówione powyżej zasady dotyczące utworów pracowniczych i pracowniczych utworów naukowych należy odnosić osobno do każdego ze współtwórców. Może się zatem okazać, że część współtwórców zachowuje pełnię praw, podczas gdy pozostali przenieśli swoje prawa lub są związani pierwszeństwem publikacji przysługującym pracodawcy.

\section{- Utwory połączone}

Prawo autorskie odróżnia od współtwórczości „połączenie odrębnych utworów w celu wspólnego rozpowszechniania" dokonane przez samych twórców (art. 10 pr. aut.). Występują oczywiście praktyczne trudności związane $z$ ustaleniem, czy mamy do czynienia ze współtwórczością, czy z utworami połączonymi. Konsekwencje pomyłki 
nie muszą być jednak szczególnie dotkliwe, gdyż na gruncie art. 10 pr. aut. dysponowanie utworami połączonymi wymaga zgody wszystkich twórców, podobnie jak dysponowanie utworem współautorskim. Inaczej są tylko określone zasady pozwalające odmówić takiej zgody, co w przypadku sporu i tak będzie musiało być rozstrzygnięte przez sąd.

\section{- Utwory zbiorowe}

Współtwórczość oraz połączenie utworów to z kolei odrębne kategorie względem uregulowanego $\mathrm{w}$ art. 11 pr. aut. utworu zbiorowego (np. encyklopedia, czasopismo i inne publikacje periodyczne). Prawa do takiego utworu oraz do jego tytułu przysługują z mocy ustawy producentowi lub wydawcy.

Twórcy zachowują jedynie prawa do swoich poszczególnych części mających samodzielne znaczenie (np. referat $\mathrm{w}$ publikacji pokonferencyjnej), tak zwanych utworów składowych. Do wydania utworu zbiorowego wystarcza, aby producent lub wydawca uzyskał tylko ich zgodę na włączenie utworu składowego do utworu zbiorowego oraz na rozpowszechnianie w określony sposób (np. na sprzedaż wydrukowanych egzemplarzy). W praktyce jednak wielu producentów i wydawców domaga się od autorów podpisywania umów przenoszących autorskie prawa majątkowe $\mathrm{w}$ dość szerokim zakresie. Po podpisaniu takiej umowy, autor nie może już samodzielnie dysponować utworem składowym na polach eksploatacji, na których doszło do przeniesienia praw.

Zatem, umieszczenie w otwartym dostępie całego utworu zbiorowego oznacza przede wszystkim konieczność uzyskania zgody producenta lub wydawcy i ewentualnie - w zależności od konkretnej sytuacji prawnej - również konieczność uzyskania zgód twórców utworów składowych.

\subsection{Wykorzystanie cudzych materiałów}

Publikacje naukowe nie powstają z niczego. Praktykowanie nauki powszechnie polega na wykorzystywaniu wcześniej istniejących mate- 
riałów, w tym materiałów cudzego autorstwa. Upraszczając, wykorzystanie wcześniej istniejących materiałów stanowiących utwory (lub przedmioty praw pokrewnych) można podzielić na trzy kategorie, biorąc pod uwagę kryterium stopnia ich wykorzystania: (1) tworzenie opracowań utworów, (2) tworzenie utworów inspirowanych, (3) wykorzystanie elementów chronionych w granicach dozwolonego użytku.

\section{- Opracowania utworów}

W największym skrócie, opracowanie powstaje w wyniku twórczego przekształcenia chronionego prawem autorskim sposobu wyrażenia zaczerpniętego $\mathrm{z}$ cudzego utworu. Ustawa o prawie autorskim nie definiuje jednak opracowania, wylicza tylko przykłady (art. 2 ust. 1 pr. aut.): tłumaczenie, przeróbka, adaptacja.

Opracowanie (zwane również utworem zależnym) jest przedmiotem prawa autorskiego odrębnym od utworu oryginalnego. Twórcy opracowania przysługują zatem osobne prawa autorskie osobiste i majątkowe (z uwzględnieniem opisanych już wyjątków, kiedy prawa majątkowe należą do innej osoby). Przenoszenie praw majątkowych do opracowania jest niezależne od przenoszenia praw majątkowych do oryginału. Jednak na korzystanie z opracowania i na rozporządzanie nim potrzebne jest zezwolenie od osoby uprawnionej do oryginału (stąd określanie opracowań jako utworów zależnych - wykonywanie prawa do nich zależy od uzyskania takiego zezwolenia). Jeżeli zatem publikacja naukowa jest opracowaniem (np. tłumaczeniem) cudzego utworu, to na umieszczenie jej w otwartym dostępie należy uzyskać zgodę uprawnionego do opracowania oraz zgodę uprawnionego do oryginału.

Co istotne, publikacjom umieszczonym w otwartym dostępie libre towarzyszy zgoda na korzystanie $z$ ich opracowań. Zgoda taka jest zawarta w każdej wolnej licencji (przypomnijmy, że licencje CC z klauzulą ND, które zakazują korzystania z opracowań, nie są wolnymi licencjami). Zatem użytkownik publikacji stanowiącej opracowanie innej publikacji, znajdującej się już w otwartym dostępie libre, musi jedynie uzyskać zgodę uprawnionego do opracowania. Zgodę taką jest łatwiej uzyskać, jeżeli wolna licencja zawiera klauzulę „copyleft" (w licen- 
cjach CC nazywaną klauzulą SA, „Na tych samych warunkach”). Tu także przypomnijmy, że klauzula ta wymaga, aby licencjodawca rozpowszechniający opracowanie licencjonowanego utworu udostępniał je na takiej samej licencji jak ta, na której udostępniony był oryginał. Celem tego typu klauzul jest właśnie zagwarantowanie otwartego dostępu nie tylko do samego oryginału, ale i do opracowań utworów.

\section{- Utwory inspirowane}

Prawo autorskie przeciwstawia opracowaniom utwory inspirowane (art. 2 ust. 4 pr. aut.). Utwory inspirowane także nie zostały zdefiniowane $\mathrm{w}$ ustawie, można jednak przyjąć, że do ich powstania dochodzi w przypadku zaczerpnięcia $z$ cudzego utworu elementów niechronionych prawem autorskim, takich jak idee i zasady. Tworzenie utworów inspirowanych, korzystanie $z$ nich i rozporządzanie nimi nie stanowi wkroczenia w prawa wyłączne osób uprawnionych do utworów stanowiących źródło inspiracji, więc umieszczenie utworu inspirowanego $\mathrm{w}$ otwartym dostępie nie musi być konsultowane $\mathrm{z}$ tymi osobami. Zasady rzetelności naukowej nakazują jednak wskazywać źródła inspiracji (szerzej: źródła i autorstwo cudzych idei stanowiących podstawę publikacji naukowej).

Szczególnym przykładem utworu inspirowanego będzie -- naszym zdaniem -- publikacja naukowa stworzona na podstawie programu komputerowego lub bazy danych. Chodzi tu o publikacje opisujące algorytm programu lub w inny sposób odnoszące się do programu bez podawania jego zapisu (kodu), oraz o publikacje opisujące bazę danych bez kopiowania elementów tej bazy. W naszym przekonaniu w takich sytuacjach nie dojdzie zazwyczaj do styku praw do publikacji naukowych z prawami do programów komputerowych lub baz danych. Cały czas trwa jednak debata nad prawną ochroną algorytmów czy schematów baz danych.

\section{- Dozwolony użytek}

Niezależnie od opracowań i utworów inspirowanych występują utwory, w których wykorzystano chroniony prawem autorskim sposób 
wyrażenia oryginałów (np. fragmenty tekstu), podobnie jak w opracowaniach. Wykorzystanie to nie nosi jednak znamion twórczego przekształcenia koniecznego do powstania opracowania.

Legalne posługiwanie się chronionym materiałem cudzego autorstwa w publikacji naukowej możliwe jest na dwa sposoby. Po pierwsze, można to zrobić za wyraźną zgodą (licencja) uprawnionego. Po drugie, można to zrobić bez zgody uprawnionego, pod warunkiem dokładnego spełnienia wszystkich wymagań określonych w przepisach o dozwolonym użytku.

Granice wykorzystania cudzego utworu na podstawie licencji wyznacza w zasadzie tylko wyobraźnia stron umowy licencyjnej, choć prawo autorskie dość istotnie ogranicza swobodę umów. Z punktu widzenia otwartego dostępu, zgoda uprawnionego powinna objąć nie tylko samo wykorzystanie jego utworu w publikacji, lecz także jego rozpowszechnianie $w$ sposób wynikający $z$ wybranego modelu otwartego dostępu. Przypomnijmy, że wolne licencje takie jak CC-BY lub CC-BY-SA zawierają taką zgodę. Oznacza to, że publikacje znajdujące się już $\mathrm{w}$ otwartym dostępie libre można $\mathrm{w}$ szerokim zakresie wykorzystywać w innych publikacjach. Należy oczywiście pamiętać o przestrzeganiu postanowień tych licencji.

Przed ubieganiem się o licencję warto jednak zbadać, czy wykorzystanie fragmentu cudzego utworu we własnej publikacji naukowej nie będzie się mieściło w granicach dozwolonego użytku. W grę wchodzić będzie głównie cytowanie, uregulowane w art. 29 ust. 1 pr. aut. Cytowanie dozwolone jest także w stosunku do programów komputerowych oraz baz danych, a zatem $w$ granicach określonych w art. 29 ust. 1 pr. aut. można w publikacjach naukowych przytaczać fragmenty zapisu programów oraz zawartość baz danych.

Jak wyjaśnialiśmy wcześniej, bazy danych mogą być chronione zarówno prawem autorskim, jak i prawem sui generis. W przypadku, gdy w grę wchodzi ten drugi reżim ochronny (alternatywnie lub łącznie $z$ prawem autorskim), korzystanie $z$ bazy danych $w$ publikacji musi respektować prawa jej producenta. Podobnie jak powyżej, jest to legalne albo po uzyskaniu wyraźnej zgody producenta, albo bez zgody w granicach wynikających $z$ ustawy o ochronie baz danych. Ustawa ta dopuszcza korzystanie bez zgody producenta nawet $z$ istotnej czę- 
ści bazy danych w charakterze ilustracji, w celach dydaktycznych lub badawczych, ze wskazaniem źródła, jeżeli takie korzystanie byłoby uzasadnione niekomercyjnym celem, dla którego wykorzystano bazę (art. 8 ust. 1 pkt 2 ubd). Jest to odpowiednik występującego w prawie autorskim pojęcia dozwolonego cytatu.

W praktyce wykształcił się jednak zwyczaj zwracania się o zgodę na umieszczenie w publikacji naukowej cudzych utworów, takich jak ilustracje, fotografie, tabele. Jest on w dużej mierze efektem braku pewności prawnej co do możliwości cytowania tego typu utworów. W związku z tymi wątpliwościami, autor publikacji zawierającej cudze ilustracje, fotografie, tabele itp., który nie jest przekonany o możliwości skorzystania $z$ nich w ramach dozwolonego użytku i w związku z tym uzyskał zgodę od uprawnionych, powinien rozważyć albo ich usunięcie przed umieszczeniem $\mathrm{w}$ otwartym dostępie, albo dodatkowe uzgodnienie tej kwestii z uprawnionymi. Konieczna jest jednak szczególna staranność przy prowadzeniu takich uzgodnień, zwłaszcza jeżeli publikacja ma być następnie umieszczona w otwartym dostępie libre. Zgoda uzyskana od uprawnionego do takiego materiału musi być kompatybilna $z$ wybraną przez autora wolną licencją. $Z$ niekompatybilnością dwóch różnych licencji mamy do czynienia wtedy, gdy nie jest możliwe jednoczesne spełnienie postanowień ich obu.

Z uwagi na opisaną wyżej praktykę, korzystne może być odnalezienie ilustracji, fotografii lub tabel udostępnionych na wolnej licencji. Taka licencja zawiera szeroką zgodę na korzystanie z utworu, co zazwyczaj rozwiązuje problem wykorzystania go w publikacji. Jednak również w takim przypadku należy zwracać uwagę na kwestie kompatybilności licencji. Licencja nie może zakazywać lub nakazywać autorowi publikacji działań lub zaniechań sprzecznych z działaniami lub zaniechaniami zakazanymi lub wymaganymi w licencjach innych wykorzystanych materiałów. Licencje zawierające klauzule „copyleft” mogą z kolei wymusić wybór licencji dla całej publikacji, jeżeli publikacja stanowi opracowanie materiału nią objętego. Naszym zdaniem, umieszczenie $\mathrm{w}$ artykule np. fotografii jako ilustracji analizowanego przedmiotu nie będzie zwykle prowadziło do powstania jej opracowania.

Podsumowując, utwór z zapożyczeniami dopuszczonymi na podstawie przepisów o dozwolonym użytku jest samodzielnym utworem, 
na korzystanie z którego nie jest potrzebna zgoda uprawnionych do wykorzystanych utworów. Autor takiego utworu nie musi więc konsultować z nimi decyzji o umieszczeniu utworu w otwartym dostępie. W przypadku otwartego dostępu libre, udzielenie wolnej licencji do utworu nie oznacza oczywiście udzielenia licencji na wykorzystane w nim cudze materiały. Tym bardziej należy zatem dbać o poprawne oznaczanie np. cytatów (co skądinąd jest wymogiem legalnego cytowania). W przypadku utworu $z$ zapożyczeniami przekraczającymi dozwolony użytek, jego umieszczenie w otwartym dostępie wymaga zgody uprawnionych do wykorzystanych utworów. Otwarty dostęp libre do takiej całości jest możliwy tylko wtedy, gdy także ci uprawnieni udzielą wolnej licencji lub upoważnią do tego autora publikacji. Z tego punktu widzenia warto - gdy jest to możliwe -- korzystać z ilustracji, fotografii itp. udostępnianych na wolnych licencjach.

\subsection{Zachowanie lub nabycie koniecznych uprawnień}

Ustalenie, kto jest podmiotem praw autorskich do danej publikacji naukowej, pozwala przejść do kolejnego etapu, jakim jest pozyskanie od tego podmiotu zgody w zakresie koniecznym do wdrożenia określonego modelu otwartego dostępu. Zakres potrzebnej zgody będzie zależeć od wybranego modelu. Zanim jednak wyjaśnimy tę kwestię, przedstawimy podstawowe informacje o prawnych sposobach uzyskiwania takiej zgody.

\section{- Umowy z zakresu prawa autorskiego}

Zezwolenia na korzystanie $z$ utworu $\mathrm{w}$ określony sposób udzielane są zazwyczaj $\mathrm{w}$ postaci umów licencyjnych. Licencje mogą być niewyłączne lub wyłączne. Licencje niewyłączne nie gwarantują licencjobiorcy wyłączności korzystania z utworu i uprawniony może udzielić na danym polu eksploatacji wielu takich licencji różnym podmiotom. Natomiast po udzieleniu licencji wyłącznej na danym polu eksploatacji, uprawniony nie może już udzielić licencji na tym polu nikomu innemu. Udzielenie licencji niewyłącznej oznacza, że uprawniony zachował swoje prawa, zezwalając jedynie licencjobiorcy na korzysta- 
nie $z$ nich. Licencje wyłączne są postrzegane przez niektórych prawników jako trwałe uszczuplenie praw, a nie tylko umowne zezwolenie, co jednak nie wynika z przepisów w sposób wyraźny. Trwałe uszczuplenie zachodzi niewątpliwie w przypadku trzeciego rodzaju umów - umów przenoszących autorskie prawa majątkowe.

Przeniesienie praw na inny podmiot oznacza, że dotychczasowy uprawniony je traci, a tym samym traci możliwość zezwalania na korzystanie z utworu (w zakresie - tj. „na polach eksploatacji” w jakim przeniósł swoje prawa na nabywcę). Poza wskazywaniem pól eksploatacji, zakres przenoszonych praw można ograniczać stosując inne kryteria, np. czasowe lub terytorialne. Osoba, która nabyła prawa majątkowe na określonych polach eksploatacji może na nich korzystać $z$ utworu sama lub udzielać innym osobom licencji na korzystanie $z$ utworu na tych polach. Natomiast licencjobiorca (zarówno niewyłączny, jak i wyłączny) nie może upoważniać osób trzecich do korzystania z utworu, chyba że uzyska na to zgodę licencjodawcy (art. 67 ust. 3 pr. aut.). Takie upoważnienia udzielane przez licencjobiorcę we własnym imieniu za zgodą licencjodawcy zwane są sublicencjami (dalszymi licencjami). Stronami sublicencji są licencjobiorca (sublicencjodawca) i użytkownik (sublicencjobiorca).

Od sublicencji trzeba odróżnić licencje udzielane w imieniu licencjodawcy przez upoważnioną przez niego osobę. Upoważnienie takie przyjmuje postać pełnomocnictwa i może być połączone $z$ umową zlecenia lub agencji zawartą $z$ taką osobą. Można też sobie wyobrazić połączenie pełnomocnictwa do udzielania licencji oraz licencji. W takim przypadku, licencjobiorca będzie upoważniony do korzystania $z$ utworu samodzielnie (w ramach uzyskanej licencji), a ponadto do zezwalania na to innym (na podstawie uzyskanego pełnomocnictwa). Zezwolenia te będą licencjami zawartymi pomiędzy licencjodawcą (reprezentowanym przez licencjobiorcę) a użytkownikami, a nie sublicencjami.

\section{- Zakres praw koniecznych dla otwartego dostępu gratis}

Umieszczenie publikacji w otwartym dostępie gratis nie wymaga dysponowania pełnym zakresem autorskich praw majątkowych. Naszym 
zdaniem wystarcza do tego posiadanie praw lub licencja na korzystanie $z$ utworu na polu eksploatacji określanym jako „publiczne udostępnianie utworu w taki sposób, aby każdy mógł mieć do niego dostęp w miejscu i czasie przez siebie wybranym" (art. 50 pkt 3 pr. aut.), przez co w największym skrócie należy rozumieć „Internet”. Otwarty dostęp gratis polega bowiem właśnie na korzystaniu z utworu na tym polu eksploatacji. W praktyce może być konieczne dysponowanie prawami w szerszym zakresie. Jeżeli na przykład przed umieszczeniem publikacji w Internecie konieczna jest jej digitalizacja, to należy uzyskać prawa także na polu „zwielokrotnianie techniką cyfrową”.

Umowa, z której swoje prawa wywodzi osoba chcąca umieścić utwór w otwartym dostępie, nie może oczywiście zawierać oprócz tego żadnych wyraźnych lub dających się z niej wyinterpretować zakazów takiego działania. Dla przykładu, umowa licencyjna zezwalająca na korzystanie $z$ utworu na wskazanych wyżej polach eksploatacji mogłaby jednocześnie nakazywać licencjobiorcy stosowanie zabezpieczeń technicznych $\mathrm{w}$ dostępie do utworu. $\mathrm{W}$ takim przypadku umieszczenie utworu w otwartym dostępie (nawet w modelu gratis) byłoby sprzeczne $z$ postanowieniami umowy.

\section{- Zakres praw koniecznych dla otwartego dostępu libre}

Umieszczenie utworu $\mathrm{w}$ otwartym dostępie libre oznacza przede wszystkim udzielenie do niego wolnej licencji. Wolne licencje zawierają bardzo szerokie zezwolenia na korzystanie $z$ utworu na wszystkich znanych polach eksploatacji. Wolnej licencji może udzielić tylko ten, kto:

a) ma prawa na wszystkich znanych polach eksploatacji i jednocześnie nie udzielił licencji wyłącznej do utworu na żadnym $z$ nich (licencja wyłączna na danym polu zobowiązuje bowiem do nieudzielania innym osobom licencji na tym polu); albo

b) jest licencjobiorca, któremu osoba wskazana w pkt. (a) przyznała uprawnienia wystarczające do udzielania sublicencji (tj. licencji dalszych) o treści zgodnej z wybranym wzorem wolnej licencji. Wolne licencje nie stoją natomiast $\mathrm{w}$ konflikcie $z$ innymi licen- 
cjami niewyłącznymi. Na przykład, autor może udzielić niewyłącznej i odpłatnej licencji wydawnictwu na wydanie utworu drukiem lub umieszczenie go w elektronicznej bazie danych wydawnictwa, a jednocześnie samodzielnie umieścić ten sam utwór w otwartym dostępie udzielając do niego wolnej licencji.

Co istotne, przeniesienie praw do utworu powoduje wygaśnięcie licencji udzielonych wcześniej na korzystanie z niego, przynajmniej według niektórych interpretacji prawa autorskiego (przepisy nie są jasne $\mathrm{w}$ tym zakresie). $\mathrm{Z}$ kolei udzielenie licencji wyłącznej pomimo istniejącej wcześniej licencji niewyłącznej na tym samym polu (w tym wolnej licencji) może skutkować co najmniej odpowiedzialnością licencjodawcy wobec licencjobiorców. Dlatego też po udzieleniu wolnej licencji lepiej powstrzymać się z przenoszeniem praw oraz udzielaniem licencji wyłącznych.

Konstrukcje prawne pozwalające np. przenieść prawa i utrzymać w mocy wcześniej udzieloną wolną licencję (lub inną licencję) są co prawda możliwe, wymagają jednak przygotowania specjalnie zaprojektowanych umów. W takich umowach należy co najmniej wskazać na fakt udzielenia wolnej licencji i zobowiązać nabywcę do wywiązywania się z jej postanowień względem licencjobiorców lub nawet do jej wyraźnego potwierdzenia (odnowienia). 


\section{Wdrażanie otwartego dostępu z perspektywy autora}

W niniejszym rozdziale analizujemy podstawowe kwestie prawne, jakie napotyka autor publikacji naukowej, który chce umieścić ją W otwartym dostępie. W pierwszej kolejności wyjaśniamy znaczenie ogólnych zasad omówionych w poprzednim rozdziale z punktu widzenia autora (3.1), a następnie analizujemy sposoby zachowania przez autora praw koniecznych do umieszczenia jego publikacji w otwartym dostępie (3.2). W ostatnim podrozdziale przedstawiamy przykład ilustrujący jedną z możliwości wdrożenia otwartego dostępu, jakimi dysponuje autor (3.3).

\subsection{Ustalenie uprawnionego}

Najważniejszą kwestią jest ustalenie, czy autor jest podmiotem praw do swojej publikacji naukowej. Z punktu widzenia autora publikacja naukowa może być:

a utworem naukowym, do którego przysługuje mu pełnia praw autorskich osobistych i majątkowych (reguła ogólna - art. 8 pr. aut.);

b utworem naukowym stworzonym w ramach wykonywania przez niego obowiązków pracowniczych wobec instytucji naukowej wtedy przysługuje mu pełnia praw autorskich osobistych i majątkowych ograniczona jedynie pierwszeństwem publikacji przysługującym instytucji (w zamian za dodatkowe wynagrodzenie - art. 14 ust. 1 pr. aut.);

c utworem naukowym stworzonym $\mathrm{w}$ ramach wykonywania przez niego obowiązków pracowniczych wobec pracodawcy niebędącego 
instytucją naukową - w tej sytuacji autorskie prawa majątkowe przysługują pracodawcy - art. 12 pr. aut.;

d utworem naukowym, do którego prawa zostały przeniesione na nabywcę na skutek specjalnych postanowień umowy o pracę lub innej umowy.

Choć z punktu widzenia przepisów prawa autorskiego zasadą jest sytuacja opisana w punkcie (a), to w praktyce częstsze mogą być sytuacje opisane $\mathrm{w}$ pozostałych punktach. W sytuacjach opisanych $\mathrm{w}$ punktach (b)-(d) umieszczenie publikacji w otwartym dostępie oznacza dla autora konieczność uzgodnień ze wskazanymi tam podmiotami.

Oczywiście nie zawsze publikacja naukowa jest dziełem wyłącznie jednego twórcy. Autor może dzielić swoje prawa z innymi uczestnikami procesu twórczego. Umieszczenie w otwartym dostępie publikacji, która jest utworem współautorskim lub składa się z utworów połączonych, wymaga jednomyślności wszystkich uprawnionych. Natomiast umieszczenie w otwartym dostępie utworu zbiorowego wymaga zgody producenta (wydawcy) oraz zgód autorów wszystkich utworów składowych. Autor może samodzielnie umieścić w otwartym dostępie jedynie swój utwór składowy, a i to tylko wtedy, gdy nie przeniósł na wydawcę praw do tego utworu na polach eksploatacji koniecznych dla danego modelu otwartego dostępu.

Współtwórcy lub twórcy utworów połączonych, którzy są jednomyślni co do umieszczenia ich publikacji naukowej w otwartym dostępie, mogą upoważnić jednego z nich lub osobę trzecią do stosownych działań. Takie pełnomocnictwo nie musi być jednak udzielone w szczególnej formie. W zależności od wybranego modelu otwartego dostępu upoważnienie może dotyczyć wyłącznie czynności technicznych (umieszczenie $\mathrm{w}$ internetowym repozytorium) lub także prawnych (udzielenie licencji). Należy zadbać o wystarczająco wyraźną treść upoważnienia oraz o jego potwierdzenie przez wszystkich uprawnionych.

Brak jednomyślności współtwórców może oznaczać konieczność rezygnacji z otwartego dostępu. Mianowicie, jeżeli udostępnieniu sprzeciwia się któryś ze współautorów, autor może albo spróbować wyodrębnić swój wkład i udostępnić tylko tak wydzieloną część utworu, albo zażądać rozstrzygnięcia przez sąd. Ale postępowanie sądowe jest mało praktycznym rozwiązaniem chociażby dlatego, że 
nie gwarantuje uzyskania zgody - sąd orzeka uwzględniając interesy wszystkich współtwórców (art. 9 ust. 3 pr. aut.). Natomiast w przypadku, gdy udostępnieniu utworu sprzeciwia się któryś spośród twórców utworów połączonych, autor jest w o tyle lepszej sytuacji, że z uwagi na faktyczną odrębność swojego utworu może go łatwo wydzielić i udostępnić samodzielnie tylko ten utwór.

Jak już wspomnieliśmy, brak zgody wydawcy utworu zbiorowego nie przeszkadza autorowi w umieszczeniu w otwartym dostępie swojego utworu składowego, o ile nie przeniósł praw do niego na wydawcę. W praktyce sytuacja może być jednak bardziej skomplikowana. Niektórzy wydawcy stoją na stanowisku, że zmiany wprowadzane do manuskryptów autorskich podczas procesu wydawniczego prowadzą do wniesienia do publikacji wkładu twórczego. Zakładając, że tak jest w istocie, mielibyśmy do czynienia z opracowaniem utworu lub z powstaniem utworu współautorskiego. Istotnie, w procesie redakcji wydawca może do publikacji dodać własne twórcze elementy, a poza tym może być chroniony jej całościowy wygląd, jeżeli jest efektem twórczego wyboru elementów, nawet nietwórczych. Z drugiej strony, trudno odnaleźć wkład twórczy w działaniach takich jak wykonanie korekty językowej, która podlega zewnętrznym i w miarę ściśle określonym ograniczeniom reguł językowych. Wielu wątpliwości można zatem łatwo uniknąć umieszczając w otwartym dostępie ostateczną wersję autorską, a nie wersję po opracowaniu redakcyjnym. Najlepiej jednak po prostu zawczasu zadbać o to, żeby w umowie zawieranej z wydawcą znalazły się postanowienia, umożliwiające umieszczanie $\mathrm{w}$ otwartym dostępie utworu $\mathrm{w}$ wersji przetworzonej przez wydawcę lub od razu wybrać wydawcę działającego już w modelu otwartego dostępu.

\subsection{Zachowanie koniecznych praw}

Zakres praw, jakimi musi dysponować autor, aby samodzielnie umieścić publikację w otwartym dostępie, zależy od tego, czy autor chce wdrożyć otwarty dostęp gratis czy libre. Kwestie te omówiliśmy już w podrozdziale 2.7. Poniżej rozważamy różne sposoby postępowania możliwe z punktu widzenia autora. 


\section{- Uważne negocjowanie umów}

Najbardziej pożądanym rozwiązaniem jest takie formułowanie umów dotyczących publikacji naukowych (w tym umów o pracę), aby umieszczanie tych publikacji $\mathrm{w}$ otwartym dostępie było możliwe bez konieczności rozwiązywania lub aneksowania tych umów. Chodzi tu o wprowadzenie do umowy postanowień, które zapewnią autorowi wystarczający zakres praw po podpisaniu umowy. Poza uważnym wymienianiem w takiej umowie pól eksploatacji, czyli zakresu objętych nią praw, zdecydowanie warto wyraźnie zaznaczyć, że jednym $z$ jej celów jest zachowanie przez autora praw koniecznych do samodzielnego umieszczania publikacji w otwartym dostępie. Warto również opisać, jak strony rozumieją pojęcie otwartego dostępu.

Dla przykładu, odpowiednio skonstruowane umowy mogą umożliwić autorowi współpracę $z$ wydawnictwem oraz równoległe samodzielne umieszczenie danej publikacji w otwartym dostępie. W praktyce wymaga to zwykle poproszenia wydawcy o zmianę stosowanego przez niego standardowego wzorca umowy wydawniczej. Często bowiem taki wzorzec to umowa przenosząca prawa w bardzo szerokim zakresie. Warto mieć ponadto świadomość, że niektórzy wydawcy odmawiają przyjęcia do druku materiałów już wcześniej opublikowanych. Autorzy, którzy chcą współpracować z takimi wydawcami, muszą powstrzymać się z samodzielnym umieszczeniem publikacji w otwartym dostępie co najmniej do czasu wyjaśnienia tej kwestii.

\section{Analizowanie zawartych umów}

Jeżeli doszło już do podpisania umowy przenoszącej prawa autorskie lub udzielenia licencji wyłącznej i nie ma możliwości jej zmiany, to należy mimo wszystko zbadać, jakie prawa pozostawia ona autorowi. Może to pozwolić na umieszczenie publikacji przynajmniej w otwartym dostępie gratis (otwarty dostęp libre wymaga zachowania nieobciążonych praw na wszystkich znanych polach eksploatacji).

Zgodnie z zasadą specyfikacji pól eksploatacji, umowa obejmuje tylko te pola eksploatacji, które zostały w niej wyraźnie wymienione (art. 41 ust. 2 pr. aut.). Wszelkie wątpliwości powinny być 
w zasadzie rozstrzygane na korzyść autora (twórcy), co oznacza, że brak wzmianki o określonym polu eksploatacji w umowie powoduje zachowanie go po stronie twórcy. Ale ustalenie, czy strony faktycznie wskazały w umowie określone pole eksploatacji, następuje w drodze wykładni. Podczas wykładni uwzględniane są między innymi okoliczności towarzyszące zawarciu umowy oraz zachowanie stron $\mathrm{w}$ trakcie jej zawierania i wykonywania.

Ponadto, poza przeniesieniem praw na określonych w umowie polach eksploatacji, umowy mogą zawierać dodatkowe klauzule, np. zakazujące autorowi konkurowania $z$ wydawcą lub podobne. Zatem, każda umowa dotycząca utworu, który autor chciałby następnie umieścić w otwartym dostępie, powinna być dokładnie przeanalizowana. Analiza umów jest wskazana także $z$ tego powodu, że niekiedy umowa może otwierać twórcy dodatkowe wyjścia $z$ sytuacji, nawet jeżeli co do zasady prawa autorskie zostały przeniesione na wydawcę (np. umowne prawo wypowiedzenia lub odstąpienia).

\section{- Aneksowanie lub rozwiązywanie umów za porozumieniem stron}

Aneksowanie umów, które nie pozostawiają autorowi wystarczających uprawnień, wymaga oczywiście obopólnej zgody stron. W zależności od tego, jaka umowa została zawarta, konieczne będzie albo podpisanie nowej umowy przenoszącej prawa $z$ powrotem na autora (odpowiednio: rozwiązującej licencję wyłączna), albo aneksowanie podpisanej umowy przez udzielenie autorowi licencji zwrotnej do jego utworu, upoważniającej go do udzielania wolnych licencji (w tym wypadku jako sublicencji). Rozwiązania te różnią się od strony formalno-prawnej, ale w praktyce prowadzą do tego samego efektu możliwości umieszczenia publikacji w otwartym dostępie samodzielnie przez autora.

\section{- Wykorzystanie przepisów chroniących twórcę}

Jeżeli niekorzystna dla autora umowa została już podpisana, a nabywca praw autorskich nie wykazuje woli współpracy przy jej rozwiązaniu lub aneksowaniu (względnie nie można się z nim skontaktować, np. 
z uwagi na upływ czasu), autor może aktywnie korzystać z przepisów prawa autorskiego chroniących twórcę. Jednym $z$ takich przepisów jest zakaz kontraktowania co do nieznanych pól eksploatacji (art. 41 ust. 4 pr. aut.). Innymi słowy, prawa do korzystania z utworów w określony sposób można przenosić tylko od momentu, w którym dane pole eksploatacji zaistniało w sensie technicznym i ekonomicznym. Upraszczając można założyć, że umowy zawierane w czasach, gdy Internet czy inne tego typu technologie informacyjno-komunikacyjne w ogóle nie istniały, w żaden sposób nie mogły objać pól eksploatacji koniecznych do wdrożenia otwartego dostępu gratis. Autorzy mogą wykorzystać tę regulację prawa autorskiego, aby umieszczać w otwartym dostępie gratis swoje archiwalne publikacje, nawet jeżeli przenieśli do nich autorskie prawa majątkowe w szerokim zakresie. Prawo nie dostarcza jednak żadnych wskazówek pozwalających dokładnie ustalić datę, po której „internetowe” pola eksploatacji zaistniały. Im później zawarto umowę, tym większe ryzyko, że mogła ona skutecznie przenieść prawa na tych polach, o ile oczywiście zostały one w niej wystarczająco wyraźnie wymienione (art. 41 ust. 2 pr. aut.). Co istotne, rozwiązanie opisane $\mathrm{w}$ niniejszym akapicie nie pozwala na umieszczenie publikacji w otwartym dostępie libre.

Pewne dodatkowe możliwości dają autorowi przepisy art. 56 i 57 pr. aut. Pierwszy z nich pozwala twórcy odstąpić od umowy lub wypowiedzieć ją ze względu na istotne interesy twórcze. Jest to prawo wynikające z ustawy i nie można go wyłączyć w umowie. Przepis ten jest jednak trudny do zastosowania i obwarowany szeregiem gwarancji dla dotychczasowego nabywcy. Twórca musi przede wszystkim być w stanie wykazać, że jego istotne interesy twórcze przemawiają za rozwiązaniem umowy. Ponadto, jeżeli twórca zamierza korzystać $\mathrm{z}$ utworu (np. zdeponować go w otwartym repozytorium) w ciągu dwóch lat od odstąpienia lub wypowiedzenia, to i tak musi dotychczasowemu nabywcy zaoferować korzystanie $z$ utworu w ten sposób (art. 56 ust. 2 pr. aut.). Z kolei ust. 3 tego samego art. 56 pr. aut. ustala zasady zabezpieczania przez twórcę kosztów, jakie nabywca poniesie w wyniku odstąpienia lub wypowiedzenia. Jeżeli nabywca zażąda zabezpieczenia tych kosztów, to może się to stać warunkiem skuteczności odstąpienia lub wypowiedzenia. 
Art. 57 ust. 1 pr. aut. pozwala odstąpić od umowy lub wypowiedzieć ją, jeżeli nabywca lub licencjobiorca, który zobowiązał się do rozpowszechniania utworu, nie przystąpi do rozpowszechniania $\mathrm{w}$ umówionym terminie, a w jego braku - w ciągu dwóch lat od przyjęcia utworu. Z punktu widzenia twórców, którzy chcieliby umieszczać swoje publikacje $\mathrm{w}$ otwartym dostępie, przydatność tego przepisu jest jednak ograniczona, gdyż dotyczy on jedynie sytuacji, w których nabywca (np. wydawca) istotnie nie przystąpił do rozpowszechniania.

\subsection{Przykładowe praktyczne rozwiązanie dla autora}

Załóżmy, że autor jest pracownikiem naukowym instytucji naukowej i w ramach swoich obowiązków pracowniczych tworzy publikacje będące utworami naukowymi. Zgodnie $z$ art. 14 ust. 1 pr. aut. prawa autorskie do tych publikacji przysługują jemu, a instytucja ma jedynie pierwszeństwo publikacji. Ale w praktyce instytucje naukowe rzadko korzystają z tego pierwszeństwa, między innymi dlatego, że oznacza to konieczność zapłacenia twórcy dodatkowego wynagrodzenia. Zdarza się wręcz, że $z$ góry zrzekają się tego prawa względem wszystkich utworów naukowych swoich pracowników, na przykład poprzez postanowienia regulaminu pracy lub regulaminu „własności intelektualnej” (o czym szerzej w rozdziale 5). W takim wypadku autor może swobodnie zdecydować o umieszczeniu publikacji w otwartym dostępie, zakładając uzgodnienie tych kwestii z ewentualnymi współautorami oraz wydawcą.

Jeżeli jednak pracodawca nie zrzekł się przysługującego mu pierwszeństwa, autor powinien rozważyć następujące opcje. Może on oczywiście obstawać przy opisanym w podrozdziale 2.5 stanowisku, że pierwszeństwo nie obejmuje umieszczenia utworu w Internecie. W takim przypadku, autor może samodzielnie zdecydować o umieszczeniu publikacji w otwartym dostępie gratis nie czekając na decyzję pracodawcy. Decyzja pracodawcy będzie przy takim podejściu konieczna dopiero w przypadku otwartego dostępu libre. Udzielana $\mathrm{w}$ takim przypadku wolna licencja obejmuje bowiem wszystkie pola eksploatacji, a więc także pola odnoszące się do publikowania „tradycyjnego", zdecydowanie objętego pierwszeństwem pracodawcy. 
W praktyce bardziej prawdopodobna będzie jednak sytuacja, w której autor i pracodawca zechcą uzgodnić udostępnianie publikacji w otwartym dostępie. Na gruncie samego prawa autorskiego pracodawca nie ma jednak wielu możliwości wywierania nacisku na autora, gdyby chciał mu uniemożliwić publikację w otwartym dostępie. Skorzystanie z prawa pierwszeństwa wymaga zapłaty wynagrodzenia, którego wysokość musi zostać z twórcą uzgodniona w umowie. Umowa musi też uregulować inne istotne kwestie, a wszystkie one podlegają negocjacji. Sytuacja, w której postanowienia umowy zostałyby narzucone autorowi niezgodnie $z$ jego wolą może być wynikiem wyłącznie pozaprawnego lub wręcz nielegalnego nacisku. Przy braku takich nacisków, niedojście przez strony do porozumienia spowoduje upływ terminu wygaśnięcia pierwszeństwa. Mianowicie, pierwszeństwo opublikowania wygasa, jeżeli w ciągu sześciu miesięcy od dostarczenia utworu nie zawarto $z$ twórcą umowy o wydanie utworu albo jeżeli w okresie dwóch lat od daty jego przyjęcia utwór nie został opublikowany (art. 14 ust. 1 pr. aut.).

Można jednak zakładać, że instytucje, które nie zrzekają się $z$ góry prawa pierwszeństwa, robią to realizując przemyślaną i uzgodnioną uprzednio z pracownikami politykę. Na przykład, rozwinęły one sprawnie działające instytucjonalne wydawnictwo, zdolne płacić naukowcom wynagrodzenia lub w inny sposób rekompensujące im korzystanie $z$ prawa pierwszeństwa (np. publikacja w takim wydawnictwie ma istotny wpływ na ocenę dorobku naukowego). Należy wtedy podjąć działania aby otwarty dostęp został wpisany $\mathrm{w}$ tę politykę $\mathrm{w}$ sposób, który pozwala na zachowanie tych korzyści. O możliwych sposobach realizacji tych działań piszemy szerzej w rozdziale 5.

W przypadku, gdy instytucja naukowa nie realizuje prawa pierwszeństwa a autor zapewnił sobie swobodę dysponowania utworem, może on umieścić go w otwartym dostępie gratis lub libre, według własnego wyboru. Samodzielne wdrożenie otwartego dostępu, polegające jedynie na udostępnieniu utworu w otwartym repozytorium, może nie być korzystne dla autora z różnych względów. Korzystniejsze może być na przykład połączenie udostępnienia utworu w repozytorium $\mathrm{z}$ publikacją $\mathrm{w}$ wydawnictwie, które jest brane pod uwagę przy 
ocenie dorobku naukowego, lub publikacja w czasopiśmie działającym w modelu otwartego dostępu. W takim przypadku lepiej powstrzymać się $z$ umieszczaniem utworu $\mathrm{w}$ Internecie do momentu uzgodnienia tego $z$ wydawca, co już sygnalizowaliśmy.

$Z$ punktu widzenia autora zainteresowanego otwartym dostępem, wydawcy dzielą się na dwie grupy. Pierwsza to wydawcy działający już w modelu otwartego dostępu, prowadzący czasopisma w otwartym dostępie. Druga to wydawcy działający w mniej innowacyjny sposób lub nawet wyraźnie sprzeciwiający się otwartemu dostępowi.

Publikacja $\mathrm{w}$ wydawnictwie działającym $\mathrm{w}$ modelu otwartego dostępu nie oznacza utraty tzw. punktów do dorobku naukowego czasopisma w otwartym dostępie działają pod tym względem według takich samych zasad, jak czasopisma tradycyjne. Dzięki temu autorzy zdeterminowani, by zapewnić otwarty dostęp do swoich prac, nie muszą rezygnować $z$ recenzowanej publikacji, ani też tracić na ocenie ich dorobku naukowego. Jest to prawdopodobnie najlepszy wybór, choć i w tym wypadku należy dokładnie przestudiować postanowienia umowy $z$ wydawcą.

Natomiast połączenie otwartego dostępu i współpracy z wydawnictwem niechętnym lub przeciwnym otwartemu dostępowi może być trudne lub nawet niemożliwe. W przypadku wyboru takiego wydawnictwa, warto jednak mimo wszystko zwrócić się do niego z propozycją udzielenia niewyłącznej licencji na publikację, bez ograniczeń uniemożliwiających otwarty dostęp, zamiast stosowanego zwykle przenoszenia praw autorskich. Przesłany przez wydawnictwo wzór umowy powinien być dokładnie sprawdzony pod tym kątem, a niekorzystne dla autora postanowienia poddane negocjacjom. Pojedynczy autor może nie mieć wystarczającej siły negocjacyjnej, ale taką siłą może dysponować grupa autorów, za którą stoi konsekwentna polityka otwartego dostępu realizowana przez instytucję naukową będącą ich pracodawcą. W rozdziale 5 przedstawiamy bardziej rozbudowane propozycje realizacji takiej polityki, oparte na współpracy autorów, instytucji naukowych oraz wydawnictw. 


\section{Wdrażanie otwartego dostępu z perspektywy wydawnictwa}

W niniejszym rozdziale omawiamy prawne zagadnienia związane $z$ wydawaniem w otwartym dostępie czasopisma naukowego. W pierwszej kolejności wydawca musi zdecydować, które elementy czasopisma chciałby umieścić w otwartym dostępie (4.1). Następnie powinien pozyskać od autorów poszczególnych artykułów odpowiednie uprawnienia oraz ustalić pozostałe zasady współpracy z twórcami udostępnianych elementów czasopisma (4.2). W ostatnim podrozdziale przedstawiamy dwa warianty wdrożenia otwartego dostępu, odpowiadające dwóm zasadniczym typom wydawnictw naukowych (4.3).

Skupiamy się tu na czasopismach, ale wiele uwag będzie miało zastosowanie także do wydawców książek i innych publikacji jednorazowych.

\subsection{Elementy czasopisma w otwartym dostępie}

Dobra niematerialne funkcjonujące $w$ ramach czasopisma to nie tylko poszczególne artykuły. Każdy numer czasopisma będzie prawdopodobnie utworem zbiorowym, stanowiącym osobny przedmiot ochrony prawno-autorskiej. Jak już wyjaśnialiśmy, prawa do utworu zbiorowego jako całości przysługują z mocy ustawy jego producentowi lub wydawcy. Z kolei zbiór wszystkich opublikowanych w danym czasopiśmie artykułów stanowić będzie najprawdopodobniej bazę danych korzystająca z ochrony sui generis (a możliwe, że również z ochrony prawno-autorskiej). Prawa do baz danych przysługują także producentowi (tu: wydawcy). Ale poza samą treścią i zbiorem tej treści, 
chronione mogą być także i inne elementy czasopisma, jak jego układ, forma graficzna, tytuł, projekt okładki itp. Przysługiwanie praw do tych elementów regulują umowy zawierane indywidualnie $z$ ich twórcami, podobnie jak przysługiwanie praw do poszczególnych artykułów i innych publikowanych materiałów.

Z uwagi na mnogość przedmiotów ochrony, jakie mogą wchodzić w skład jednego czasopisma, należy zadbać, aby w otwartym dostępie znalazły się tylko te, które mają się tam znaleźć. Decyzja należy oczywiście do wydawnictwa, ale istotne jest, aby została wyraźnie zamanifestowana na zewnątrz poprzez dokładne oznaczenie elementów umieszczonych w otwartym dostępie. Uważamy, że nawet w przypadku najszerszego otwarcia nie musi dojść do udostępnienia w celu powszechnego wykorzystania takich elementów identyfikujących czasopismo jak tytuł, inne oznaczenia identyfikujące czy ogólna forma graficzna. Wręcz wskazane jest zachowanie praw wyłącznych do tych elementów lub nawet wzmocnienie ich ochrony, np. poprzez rejestrację znaków towarowych. Analogiczna praktyka stosowana jest w ramach różnych projektów wolnego oprogramowania. Wolna licencja obejmuje tworzony w ramach projektu kod programów (tu: treść czasopisma), podczas gdy elementy identyfikujące (np. nazwa, logo) nie są udostępniane w ten sposób. Pozwala to tzw. „właścicielom projektu" (tu: redakcji czasopisma) zachować kontrolę nad kształtem i rozwojem oficjalnej wersji projektu, nawet jeżeli jego produkty mogą być swobodnie wykorzystywane przez wszystkich użytkowników.

$\mathrm{Z}$ punktu widzenia zapewnienia otwartego dostępu do publikacji naukowych wystarczające jest udostępnienie poszczególnych artykulów. W przypadku otwartego dostępu gratis oznacza to po prostu opublikowanie ich w Internecie bez ograniczeń technicznych. Jak już wyjaśnialiśmy, wszelkie materiały umieszczone w Internecie bez dodatkowych zezwoleń mogą być przez użytkowników wykorzystywane jedynie w granicach dozwolonego użytku. Dopiero w przypadku otwartego dostępu libre każdy artykuł jest ponadto udostępniany na wolnej licencji, która znacząco poszerza swobody użytkownika.

Jeżeli wolna licencja jest przypisana tylko do artykułów, to wynikające $z$ niej swobody nie rozciągają się na pozostałe elementy czasopisma (tytuł, projekt graficzny itp.) - z jednym zastrzeżeniem. 
Otóż z formalnego punktu widzenia, udostępnienie na wolnej licencji nawet wszystkich artykułów publikowanych w czasopiśmie nie oznacza co prawda, że użytkownik uzyskuje jakiekolwiek uprawnienia do bazy danych zawierającej te artykuły. Jednak w praktyce, korzystając $z$ uprawnień udzielonych mu $\mathrm{w}$ licencjach do poszczególnych artykułów, użytkownik będzie mógł we własnym zakresie odtworzyć tę bazę (pobierając po kolei wszystkie artykuły udostępnione na wolnej licencji) i opublikować ją równolegle. Natomiast jeżeli artykuły zostaną udostępnione w otwartym dostępie gratis, to takie działanie będzie nielegalne.

Kolejną istotną informacją jest to, że wolna licencja dotyczy utworu, a nie jego konkretnego egzemplarza. Udzielenie wolnej licencji do wydanego drukiem numeru czasopisma umożliwia użytkownikom jego digitalizację i umieszczenie w Internecie. I odwrotnie, wolna licencja na wersję elektroniczną zezwala na wydanie jej drukiem (choć pozaprawną barierą mogą być tu np. koszty druku). $\mathrm{Z}$ tego punktu widzenia nie ma prawnego umocowania do pojawiających się niekiedy pomysłów prowadzenia czasopisma w otwartym dostępie libre „tylko w Internecie” lub innych prób ograniczania pól eksploatacji. Opatrywanie wolną licencją tylko niektórych wersji materiałów i pozostawianie standardowej noty copyright (,wszelkie prawa zastrzeżone") na innych prowadzi tylko do wątpliwości, czy określony utwór został istotnie umieszczony w otwartym dostępie (można bowiem mieć wątpliwości, czy wolna licencja rzeczywiście została udzielona).

Podsumowując, udzielanie wolnych licencji do poszczególnych artykułów lub do całych numerów czasopisma, ale $z$ wyłączeniem elementów identyfikujących czasopismo, zapewnia, że nikt nie będzie mógł zacząć wydawać „kopii” całego czasopisma, natomiast możliwe będzie niezależne rozpowszechnianie i wtórne wykorzystywanie poszczególnych artykułów lub numerów. W praktyce oznacza to, że wydawca wprawdzie traci kontrolę nad dalszym wykorzystywaniem publikowanych $\mathrm{w}$ piśmie materiałów, zachowuje jednak kontrolę nad własną marką oraz dalszym rozwojem samego czasopisma. Konsekwencją decyzji o wydawaniu czasopisma w otwartym dostępie libre może być zatem konieczność gruntownego przebudowania modelu jego funkcjonowania, także od strony ekonomicznej. Zmiany 
te nie zawsze muszą być radykalne, zwłaszcza w przypadku wielu wydawnictw naukowych, których głównym źródłem utrzymania są publiczne dotacje, a nie prenumerata. W ich przypadku otwarty dostęp to głównie oszczędność (np. na kosztach druku) przy zachowaniu dotychczasowych przychodów. Ale nawet komercyjne wydawnictwa naukowe często w istotnym zakresie uzupełniają przychody z prenumerat opłatami za publikację pobieranymi od autorów (pochodzącymi de facto również z publicznych pieniędzy), co również ułatwia wdrożenie otwartego dostępu.

\subsection{Nabywanie praw od autorów}

Umieszczanie artykułów w otwartym dostępie wymaga nabycia stosownych uprawnień od autorów, o czym pisaliśmy już ogólnie w podrozdziale 2.7. Wydawca musi oczywiście najpierw upewnić się, czy autor jest właściwą stroną umowy, co wymaga m.in. zakwalifikowania otrzymanego artykułu do jednej z kategorii omówionych w podrozdziałach 2.4-2.6. Może się na przykład okazać, że poza autorem stroną umowy musi być też jego pracodawca lub współautorzy.

\section{- Autorskie prawa osobiste}

W odróżnieniu od autora, który chciałby samodzielnie umieścić swoją publikację w otwartym dostępie (patrz podrozdział 3.2), wydawca nigdy nie będzie podmiotem autorskich praw osobistych. W związku z tym nie da się całkowicie wykluczyć kwestii interesów autora z działań podejmowanych w ramach otwartego dostępu. Zazwyczaj nie stwarza to jednak specjalnych problemów. Niezbywalność autorskich praw osobistych oznacza bowiem tylko tyle, że artykuły muszą być umieszczane w otwartym dostępie w sposób nienaruszający „więzi twórcy z utworem" (art. 16 pr. aut.).

Takim naruszeniem byłoby np. zakłamanie co do autorstwa, naruszenie integralności utworu, uniemożliwienie nadzoru nad sposobem korzystania z niego. W normalnej sytuacji będą to jednak wyjątkowe przypadki, a możliwości powoływania się na prawa osobiste są ograniczone w sytuacji, gdy rozpowszechnienie nastąpiło w sposób 
ewidentnie zgodny z zawartą przez autora umową. Zwłaszcza, gdy taka umowa w sposób wyraźny przewiduje umieszczenie publikacji w otwartym dostępie.

\section{- Przenoszenie praw lub licencja}

Umieszczenie utworu $\mathrm{w}$ otwartym dostępie przez wydawcę przy jednoczesnym poszanowaniu autorskich praw majątkowych wymaga dłuższego omówienia. Najprostszym rozwiązaniem jest oczywiście nabycie przez wydawcę tych praw. Jest to oczywiście rozwiązanie najbardziej trwałe pod względem prawnym, tj. najtrudniejsze do jednostronnej modyfikacji. Jednak z punktu widzenia autora uważamy je za niekorzystne (patrz podrozdział 3.2). Naszym zdaniem dostępne są inne rozwiązania w zupełności wystarczające dla wydawcy, a bardziej korzystne dla autorów.

Chodzi na przykład o wdrożenie otwartego dostępu w oparciu o odpowiednią licencję. Mianowicie, zamiast przenosić swoje prawa na wydawcę, autor może je zachować i udzielić wydawcy licencji upoważniającej do udostępnienia artykułu w modelu otwartego dostępu gratis lub libre. Trzeba jednak pamiętać, że licencja jest stosunkiem umownym, który co do zasady może być jednostronnie rozwiązany (wypowiedziany). Możliwe jest „usztywnienie” tego stosunku, chociażby przez udzielanie licencji na maksymalny dopuszczony przez prawo autorskie czas określony, czyli na 5 lat (art. 68 ust. 2 pr. aut.), jednak efekt nigdy nie będzie tak trwały jak efekt umowy przenoszącej prawa.

Ale w przypadku wydawania otwartego czasopisma trwałość stosunku prawnego ma mniejsze znaczenie niż w przypadku wydawcy, który opiera swoją działalność o wyłączność wynikającą z nabywania praw autorskich. Wydawca otwartego czasopisma nie ma wielu powodów, by dążyć do maksymalnego ograniczenia możliwości współpracujących z nim autorów, a może wręcz chcieć zachować ich jak największą swobodę.

Udzielenie licencji upoważniającej do udostępnienia publikacji w otwartym dostępie gratis polega na zezwoleniu wydawcy na korzystanie z niej na "internetowym” polu eksploatacji („publiczne 
udostępnianie utworu w taki sposób, że każdy może z niego korzystać w miejscu i czasie przez siebie wybranym") i ewentualnie na innych polach, jeżeli wydawca skorzysta $z$ utworu w szerszym zakresie (np. jeżeli utwór zostanie wydrukowany lub zdigitalizowany). Umowa licencyjna może dodatkowo precyzować, jak strony rozumieją otwarty dostęp, a autor któremu zależy na tych kwestiach, będzie zapewne nalegał na wpisanie do umowy wyraźnych zakazów stosowania zabezpieczeń technicznych lub innych ograniczeń, a być może nawet wyraźnego obowiązku udostępnienia utworu. Wydawca powinien zadbać, aby takie ewentualne obowiązki nie były określone w sposób utrudniający ich wykonanie lub pozwalający zarzucić mu nieprawidłowe wykonanie umowy.

Umowa pozwalająca wydawcy na udostępnienie publikacji w otwartym dostępie libre może być skonstruowana na kilka różnych sposobów. Najprostszym rozwiązaniem jest zawarcie pomiędzy autorem a wydawcą umowy zgodnej ze wzorem wolnej licencji Creative Commons (CC-BY, CC-BY-SA). Wydawca będzie wtedy zobowiązany, aby rozpowszechniając utwór przekazywał użytkownikom informację o licencji, a w efekcie użytkownicy również staną się licencjobiorcami. Takie proste rozwiązanie nie spełni jednak oczekiwań każdego. Wolne licencje są nieodpłatne, więc udzielenie takiej licencji wydawcy przez autora pozbawi go wynagrodzenia należnego od tego wydawcy. Wolna licencja nie będzie zobowiązywać wydawcy do rozpowszechniania utworu, a jedynie uprawniać go do tego. Ponadto, szerokie wyłączenie odpowiedzialności licencjodawcy utrudni wydawcy dochodzenie ewentualnych roszczeń w przypadku wad artykułu. Wreszcie, wydawca może być zainteresowany zawarciem $\mathrm{w}$ umowie $\mathrm{z}$ autorem dodatkowych postanowień dotyczących korekty, wydawania kolejnych wydań utworu itp., które nie występują w standardowych wolnych licencjach.

\section{- Specjalnie przygotowane umowy}

Biorąc pod uwagę omówione powyżej ograniczenia związane z korzystaniem $\mathrm{w}$ stosunkach wydawcy $\mathrm{z}$ autorami $\mathrm{z}$ umów przenoszących prawa autorskie lub z korzystaniem $z$ wolnych licencji w sposób bezpośredni, znacznie korzystniejsze dla obu stron może być bardziej 
rozbudowane rozwiązanie. Polega ono na tym, że wolna licencja obowiązuje dopiero w stosunkach z użytkownikami (czytelnikami czasopisma), którzy uzyskują odpowiednio oznaczone egzemplarze. Natomiast pomiędzy autorem a wydawcą zawierana jest specjalnie przygotowana umowa, przewidująca udostępnianie publikacji czytelnikom na wolnej licencji. W zależności od wyboru stron, udostępnienie to będzie albo prawem, albo obowiązkiem wydawcy.

Dla przykładu, postanowienia umowne dotyczące udostępniania na wolnej licencji mogą przyjąć postać:

a upoważnienia (ew. zobowiązania) wydawcy do udzielania wolnych licencji w imieniu autora;

\section{lub}

b upoważnienia (ew. zobowiązania) wydawcy do udzielania użytkownikom sublicencji o treści tożsamej z treścią wybranego wzorca wolnej licencji.

Możliwe są też inne rozwiązania, jak np. zobowiązanie wydawcy do działania jako posłaniec wolnej licencji pomiędzy autorem a użytkownikiem. Różnice pomiędzy tymi rozwiązaniami mogą być niejasne dla czytelników niebędących prawnikami, ale też wszystkie one mają nieco inne konsekwencje prawne. Różnice te sprowadzają się przede wszystkim do tego, czy licencjodawcą wolnej licencji udzielonej czytelnikowi będzie wydawca, czy autor. Wybór wymaga analizy indywidualnych preferencji i okoliczności. Co istotne, udzielanie przez wydawcę wolnych licencji czytelnikom nie oznacza, że wydawca nie może pobierać od nich opłat. Wolna licencja jest nieodpłatna, ale opłaty można naliczać np. za określone usługi lub za sprzedaż fizycznego egzemplarza czasopisma.

Planując model nabywania uprawnień od autorów należy mieć na uwadze, że wydawanie czasopisma to działalność rozciągnięta w czasie. Postępujące zmiany technologiczne oraz zjawiska takie jak aktualizacje licencji Creative Commons mogą powodować konieczność renegocjacji już zawartych kontraktów. Warto zatem zawczasu zadbać o takie postanowienia umów, które pozostawią wydawcy pewien margines swobody. Trzeba tylko pamiętać, że prawo autorskie zawiera $\mathrm{w}$ tym zakresie istotne ograniczenia (np. zakaz kontraktowania co do nieznanych pól eksploatacji). Możliwe jest jednak zawarcie w umowie 
np. postanowień pozwalających wydawcy zmienić stosowany wzór wolnej licencji na inny.

\section{- Otwieranie archiwów}

Otwieranie archiwów może okazać się trudne lub niemożliwe, nawet w przypadku tych wydawców, którzy mają najlepszą politykę nabywania uprawnień. Często bowiem są to materiały objęte umowami wydawniczymi, które nie przewidywały takiej okoliczności, albo nie mogły jej przewidzieć z uwagi np. na wskazany wcześniej zakaz kontraktowania co do nieznanych pól eksploatacji. Niejednokrotnie zdarza się, że umowy zaginęły lub są niekompletne. Zazwyczaj okazuje się zatem, że jedynym prawnie bezpiecznym sposobem otwarcia takiego archiwum jest żmudne odnajdywanie poszczególnych autorów (lub ich spadkobierców) i uzyskiwanie dodatkowych zgód. Jeżeli nie można się z nimi skontaktować, mamy do czynienia z tzw. utworem osieroconym.

Co prawda, poza uprawnionymi zgodę na wykorzystywanie utworów mogą wyrażać również organizacje zbiorowego zarządzania, nawet jeżeli uprawnieni nie są w nich zrzeszeni (art. 21 ust. $2^{\wedge} 1$ pr. aut. oraz art. 752 i nast. kc). Rozwiązanie to nie jest jednak wykorzystywane w praktyce otwierania archiwów publikacji naukowych. Niektórzy decydują się nawet na digitalizowanie archiwów lub wydawanie utworów osieroconych w inny sposób bez zgody autorów, zakładając, że prawdopodobieństwo poniesienia odpowiedzialności jest niskie. Ale $z$ formalnego punktu widzenia brak zgody oznacza naruszenie praw autorskich, nawet jeżeli w praktyce okazuje się, że wielu autorów jest wręcz zadowolonych z „wznawiania” ich prac poprzez digitalizację. Warto też pamiętać, że poza samymi autorami i ich spadkobiercami roszczenia $z$ tytułu naruszeń mogą podnosić właśnie organizacje zbiorowego zarządzania. Za naruszenie praw grozi zatem realna odpowiedzialność cywilna i karna.

Na forum Unii Europejskiej przyjęto niedawno dyrektywę o utworach osieroconych, która może doprowadzić do uchwalenia przepisów wprowadzających dodatkowe legalne możliwości digitalizacji części archiwów. Na chwilę obecną jest to jednak dość odległe rozwiązanie, 
gdyż po przyjęciu dyrektywy konieczna jest jej implementacja do krajowego porządku prawnego.

\subsection{Przykładowe praktyczne rozwiązania dla wydawcy}

W niniejszym podrozdziale przedstawiamy dwa praktyczne przykłady, $z$ uwagi na funkcjonowanie $w$ polskich realiach dwóch zasadniczych typów wydawców. Pierwszy z nich to wydawca naukowy finansowany w całości lub w większej części z publicznych pieniędzy. Natomiast drugi typ to komercyjny wydawca naukowy, dla którego podstawowym źródłem finansowania jest sprzedaż i prenumerata, a w dalszej kolejności opłaty od autorów.

Poniżej omawiamy propozycje dla każdego $z$ tych dwóch typów wydawców. W każdym przypadku wdrożenie otwartego dostępu będzie jednak musiało wiązać się z wykorzystaniem własnej lub zewnętrznej infrastruktury teleinformatycznej. Jeżeli wydawca zdecyduje się na prowadzenie własnego serwisu, to $\mathrm{w}$ pewnej mierze będą do niego miały zastosowanie uwagi, które przedstawiamy w podrozdziale 5.2 omawiając repozytoria instytucjonalne.

\section{Wydawca naukowy finansowany publicznie}

Częstą praktyką wydawnictw naukowych finansowanych publicznie jest brak pisemnych umów z autorami, zwłaszcza w przypadku małych wydawnictw prowadzonych samodzielnie przez naukowców. Niektórzy $z$ nich ograniczają się nawet do publikowania tylko zasad przyjmowania tekstów. Praktycznym rozwiązaniem w takim przypadku jest uzupełnienie tej informacji o postanowienia dotyczące otwartego dostępu.

W przypadku otwartego dostępu gratis chodzi tu o wyraźną informację, że teksty przyjęte do publikacji będą udostępniane w powszechnie dostępnym Internecie bez zabezpieczeń technicznych (we własnym serwisie lub zewnętrznym repozytorium spełniającym odpowiednie wymogi).

W przypadku otwartego dostępu libre, należy umieścić dodatkowo informację, że po przyjęciu tekstu autor udziela do niego konkretnie 
wskazanej wolnej licencji (patrz opis sposobu udzielania licencji CC opisany w podrozdziale 2.3 ). W ten sposób licencja zostanie udzielona wydawcy, a $z$ uwagi na opisany w podrozdziale 2.3 mechanizm przekazywania oświadczeń o udzieleniu licencji będzie ona udzielana także czytelnikom czasopisma.

Brak pisemnych umów z autorami nie oznacza, że do zawarcia tych umów nie dochodzi. Jest to jak najbardziej dopuszczalna prawnie praktyka, gdyż licencje niewyłączne nie potrzebują formy pisemnej. Ale zawieranie takich umów na piśmie niewątpliwie zwiększa pewność prawną i porządek $\mathrm{w}$ wydawnictwie, zwłaszcza w kontekście późniejszego ustalania, jaki zakres praw przysługuje wydawcy w stosunku do archiwum. Przejście czasopisma na otwarty dostęp jest dobrą okazją do przygotowania wzoru pisemnej umowy lub przynajmniej wzoru umowy akceptowanej przez autorów drogą elektroniczną (połączoną z elektronicznym systemem przesyłania artykułów do publikacji). Co do ogólnej treści tej umowy odsyłamy do wariantów zaproponowanych w poprzednim podrozdziale.

\section{- Komercyjny wydawca naukowy}

Wydawca komercyjny dysponuje już zwykle rozbudowanymi wzorcami umów wydawniczych lub umów o podobnym charakterze. $Z$ prawnego punktu widzenia, wdrożenie otwartego dostępu oznacza dla niego przede wszystkim odpowiednie dostosowanie tych umów. Można np. zaproponować przygotowanie odpłatnej niewyłącznej licencji na publikację $\mathrm{w}$ Internecie (otwarty dostęp gratis). W celu wdrożenia otwartego dostępu libre, niewyłączna licencja powinna zostać udzielona wydawnictwu na wszystkich znanych polach eksploatacji, wraz $z$ uprawnieniem do korzystania $z$ opracowań utworu i prawem do udzielania sublicencji o treści zgodnej z dokładnie wskazanym wzorcem wolnej licencji (patrz opis sposobu udzielania licencji CC w podrozdziale 2.3). Można ewentualnie zastrzec, że sublicencja może być zgodna także z jakąkolwiek późniejszą wersją wskazanego wzorca, opublikowanego przez organizację Creative Commons, lub w inny sposób zwiększyć swobodę wyboru wolnej licencji przez wydawnictwo (np. poprzez ograniczenie się do ogólnej definicji wolnej licencji). 


\section{Wdrażanie otwartego dostępu z perspektywy jednostki naukowej}

W niniejszym rozdziale omawiamy podstawowe kwestie prawne, jakie napotyka jednostka naukowa zamierzająca wprowadzić otwarty mandat lub prowadząca otwarte instytucjonalne repozytorium publikacji naukowych. W pierwszej kolejności omawiamy zagadnienia związane $z$ otwartymi mandatami (5.1). Następnie wyjaśniamy ogólne zasady prowadzenia otwartych repozytoriów (5.2). W ostatnim podrozdziale przedstawiamy przykładowe rozwiązanie pokazujące, jak instytucja naukowa może wdrożyć otwarty mandat połączony z instytucjonalnym repozytorium (5.3).

\subsection{Otwarty mandat instytucji naukowej}

W chwili obecnej nie istnieją ani żadne przepisy prawne obligujące jednostki naukowe do nakładania otwartych mandatów, ani przepisy wprost je do tego upoważniające. Uważamy zatem, że jedynym aktualnie dopuszczalnym źródłem takiego mandatu może być umowa $z$ autorem. Umowa wymaga zgody obu stron, ale nie oznacza to jeszcze, że nie można wymagać od autora zawarcia umowy przewidującej otwarty mandat. Uważamy to za dopuszczalne w oparciu o omówiony już art. 14 pr. aut. Przypomnijmy, że w myśl tego przepisu instytucji naukowej przysługuje pierwszeństwo publikacji w odniesieniu do pracowniczych utworów naukowych. Wskazywaliśmy już na wątpliwości co do zakresu tego pierwszeństwa, a przyjmując ostrożną interpretację będzie ono obejmowało jedynie tradycyjną publikację. Zakres pierwszeństwa nie ma jednak szczególnego znaczenia praktycznego, gdyż 
jego realizacja poprzez zastosowanie art. 14 pr. aut. wprost wymaga wypłacenia autorowi wynagrodzenia. Poza tym, dla wielu autorów o wiele ważniejsze od wynagrodzenia jest to, czy publikacja będzie się liczyć na potrzeby oceny dorobku naukowego.

$\mathrm{Z}$ uwagi na sposoby oceniania tego dorobku, proste wykonanie prawa pierwszeństwa ma w polskich warunkach praktyczny sens głównie w odniesieniu do monografii. Publikacje w czasopismach są natomiast, gdy chodzi o większość instytucji naukowych, o wiele wyżej punktowane, jeżeli zostaną wydane przez uznane zewnętrzne, a nie instytucjonalne (uczelniane) wydawnictwa naukowe. $\mathrm{Z}$ uwagi na te ograniczenia za o wiele lepiej uzasadnione uważamy zastosowanie regulacji art. 14 ust. 1 pr. aut. w bardziej innowacyjny sposób. Mianowicie, zamiast korzystać z wynikającego z tego przepisu pierwszeństwa, jednostka naukowa może pozwolić pracownikowi na pierwszą publikację za pomocą swobodnie wybranej osoby trzeciej (np. wydawnictwa) wymagając jednak w zamian umieszczenia tak opublikowanego utworu w otwartym dostępie.

Istotą tego rozwiązania jest fakt, że z prawnego punktu widzenia takie zezwolenie stanowić będzie świadczenie jednostki naukowej na rzecz pracownika, w zamian za które jednostka może oczekiwać określonego świadczenia wzajemnego. Dążąc do zapewnienia otwartego dostępu, jednostka może określić je jako umieszczenie i udostępnienie przez pracownika opublikowanego przez wydawnictwo utworu w prowadzonym przez jednostkę naukową repozytorium, ewentualnie $\mathrm{w}$ połączeniu $\mathrm{z}$ udzieleniem do niego wolnej licencji. Jako alternatywę dla repozytorium instytucjonalnego można zaproponować autorowi skorzystanie $z$ wydawnictwa działającego w modelu otwartego dostępu (należy wtedy dokładnie określić kryteria oceny takiego wydawnictwa). Zależy to od tego, czy instytucja chce gromadzić dorobek naukowy pracowników we własnym repozytorium, czy wystarcza jej otwarty dostęp do tego dorobku zapewniony przez podmioty zewnętrzne.

Opisane powyżej zobowiązania (świadczenia wzajemne) autora byłyby oczywiście wymagalne dopiero wtedy, gdy istotnie skorzysta on z pierwszeństwa, którego zrzekł się jego pracodawca. Co istotne, ponieważ zobowiązania te będą wymagalne w zamian za zrzeczenie się usta- 
wowego pierwszeństwa, nie będzie naszym zdaniem konieczne płacenie autorom dodatkowego wynagrodzenia za ich wykonanie. Zgodnie bowiem $z$ treścią art. 14 ust. 1 pr. aut., autorowi przysługuje wynagrodzenie wtedy, gdy pierwszeństwo wykonuje instytucja naukowa.

Istnieją oczywiście nadal wydawnictwa atrakcyjne z punktu widzenia oceny dorobku, które jednak nie wyrażają zgody na publikowanie w otwartym dostępie. Polityka otwartego dostępu jednostki nie powinna naszym zdaniem zamykać autorom możliwości publikacji za ich pośrednictwem, natomiast powinna co najmniej zobowiązywać ich do uzasadniania ewentualnego wyboru publikacji w czasopiśmie wydawanym przez takie wydawnictwo. W każdym razie autor byłby zobowiązany do podniesienia w negocjacjach $z$ wydawnictwem kwestii otwartego dostępu.

Co istotne, praktyka w odniesieniu do utworów naukowych często polega na tym, że wydawcy oczekują płatności za wydanie publikacji, traktując działalność wydawniczą jako usługę świadczoną autorowi. $\mathrm{Na}$ marginesie, jest to istotna zmiana podstawowej zasady prawa autorskiego, zgodnie $z$ którą to twórcy przysługuje wynagrodzenie za korzystanie $z$ jego utworu. Niemniej jednak, w sytuacji gdy wydawca nie ponosi ryzyka ekonomicznego $z$ uwagi na opłatę uzyskaną od autora, odpada podstawowy argument podnoszony często w negocjacjach przeciwko otwartemu dostępowi do danej publikacji, jakim jest trudność w zarabianiu na takiej publikacji w sposób tradycyjny.

Ale toczenie wyczerpujących negocjacji nie zawsze jest konieczne. Praktyka pokazuje, że wielu wydawców godzi się na otwarty dostęp, jeżeli tylko zostaną o to poproszeni. Godzą się oni tym łatwiej, jeżeli prośba autora uzasadniona jest nałożonym na niego zobowiązaniem. Dlatego też kluczowym elementem proponowanego tu rozwiązania jest to, że składając publikację do wydawnictwa autor podlega właśnie prawnemu zobowiązaniu jednoczesnego udostępnienia jej w otwartym dostępie, w repozytorium instytucjonalnym lub zewnętrznym. Zawarcie $z$ wydawnictwem umowy, która uniemożliwi to autorowi (np. przeniesienie praw bez uzyskania zwrotnej licencji) będzie naruszeniem tego zobowiązania.

Zagraniczne jednostki naukowe często dodatkowo wspierają swoich pracowników gotowymi wzorami umów wydawniczych lub 
aneksów do już zawartych umów, w celu ułatwienia im negocjacji $z$ wydawcami, co uważamy za wysoce wskazane. Dlatego też, dodatkowym elementem proponowanego tu rozwiązania jest zobowiązanie autora do przedstawienia pracodawcy informacji o przebiegu negocjacji z wydawnictwem tak, aby pracodawca mógł go odpowiednio w nich wspierać, np. w postaci gotowych wzorców umownych. Przykładowe postanowienia, jakie mogą znaleźć się w takim wzorcu przedstawiamy w Aneksie.

\subsection{Prowadzenie otwartego repozytorium}

Otwarte repozytorium to serwis internetowy, udostępniający utwory naukowe odbiorcom. Poniżej omawiamy repozytoria instytucjonalne, czyli serwisy tworzone przez jednostki naukowe, w celu archiwizacji i udostępniania na zasadach otwartego dostępu utworów naukowych swoich pracowników. Wiele $z$ tych uwag będzie miało jednak również zastosowanie do serwisów prowadzonych przez wydawnictwa działające w modelu otwartego dostępu.

Repozytoria instytucjonalne są kluczowym narzędziem realizacji przyjętego w danej instytucji otwartego mandatu, chyba że pozwala się autorom na umieszczenie ich utworów w zewnętrznych otwartych repozytoriach. Repozytoria mogą być oczywiście prowadzone również przez instytucje, które takiego mandatu nie przyjęły, opierając się na dobrowolnym umieszczaniu i udostępnianiu publikacji przez autorów. Warto jednak zauważyć, że taki model nie gwarantuje dostępności całości ani nawet reprezentatywnej części dorobku naukowego jednostki. Otwarte mandaty są w praktyce zdecydowanie skuteczniejszym środkiem zapewnienia otwartego dostępu do większości takiego dorobku.

Organizacja repozytorium polega przede wszystkim na umożliwieniu pracownikom jednostki samodzielnej archiwizacji (self-archiving) ich dorobku naukowego w postaci elektronicznej. W przypadku wprowadzenia otwartego mandatu, jest to nie tylko prawo, ale i obowiązek pracownika. Sama archiwizacja wymaga jedynie spełnienia określonych wymagań technicznych. Natomiast w niektórych repozytoriach publiczne udostępnienie zarchiwizowanych publikacji nastę- 
puje dopiero po zbadaniu przez jednostkę naukową spełnienia dodatkowych kryteriów. Nie chodzi tu jednak o ocenę merytoryczną, tak jak w przypadku recenzowanych publikacji naukowych, lecz o ocenę formalną. Może to być na przykład sprawdzenie, czy publikacja należy do określonej dziedziny nauki. Poza oceną publikacji, jednostka naukowa zajmuje się też innymi czynnościami związanymi z utrzymaniem i administracją serwisu internetowego repozytorium.

Działalność serwisów internetowych podlega przede wszystkim ustawie o świadczeniu usług drogą elektroniczną (uśude). Oznacza to m.in. konieczność przekazywania użytkownikom i odbiorcom serwisu określonych w tych przepisach informacji oraz przygotowania regulaminu serwisu. Regulaminu serwisu nie należy mylić $z$ „Regulaminem zarządzania prawami autorskimi i prawami pokrewnymi oraz prawami własności przemysłowej oraz zasad komercjalizacji wyników badań naukowych i prac rozwojowych". Ten pierwszy dotyczy bowiem zasad świadczenia usług, w tym wypadku usług przechowywania i udostępniania publikacji (art. 8 ust. 3 uśude zawiera listę koniecznych elementów takiego regulaminu). Regulamin „własności intelektualnej” dotyczy natomiast zasad postępowania $z$ dobrami niematerialnymi uczelni. Do posiadania tego drugiego regulaminu zobowiązuje uczelnię art. 86c prawa o szkolnictwie wyższym.

Art. 14 uśude zawiera szczególną regulację ponoszenia odpowiedzialności przez podmioty świadczące tzw. usługi hostingowe. Ściśle rzecz ujmując, chodzi o usługi polegające na udostępnianiu zasobów systemu teleinformatycznego w celu przechowywania danych. Podmiot świadczący takie usługi nie ponosi odpowiedzialności za przechowywane dane jeżeli:

a nie wie o bezprawnym charakterze danych lub związanej z nimi działalności;

b w razie otrzymania urzędowego zawiadomienia lub uzyskania wiarygodnej wiadomości o bezprawnym charakterze danych lub związanej z nimi działalności niezwłocznie uniemożliwi dostęp do tych danych.

Jeżeli usługodawca świadczy usługi innego rodzaju, albo świadcząc co prawda te usługi nie spełni powyższych wymagań, a przechowuje dane o "bezprawnym charakterze” to nie zostanie zwolniony 
z odpowiedzialności. Dla przykładu, administrator serwisu, w którym użytkownik umieścił do publicznego udostępniania cudze utwory bez zgody uprawnionego, może być uznany za pomocnika tego naruszenia i ponieść związaną z tym odpowiedzialność cywilną lub karną (jeżeli oczywiście spełni ogólne przesłanki takiej odpowiedzialności, np. uda mu się przypisać winę itd.). Większość serwisów internetowych, które pozwalają swoim użytkownikom umieszczać różne materiały, czyni starania, aby korzystać z tzw. „bezpiecznej przystani” uregulowanej W art. 14 uśude. Sygnalizujemy, że trwają obecnie prace nad kompleksową nowelizacją tej regulacji.

Naszym zdaniem art. 14 uśude może mieć zastosowanie do instytucjonalnych repozytoriów dorobku naukowego, o ile oczywiście spełnią one określone $\mathrm{w}$ tym przepisie wymagania. $\mathrm{W}$ tym celu działania jednostki naukowej powinny ograniczać się do utrzymywania serwisu od strony technicznej i jego administracji tak, aby umożliwiał on przechowywanie materiałów przekazywanych przez użytkowników. Jednostka nie powinna samodzielnie podejmować czynności prowadzących do nabycia wiedzy o ewentualnym bezprawnym charakterze tych materiałów, a jedynie niezwłocznie reagować na wiarygodne wiadomości lub urzędowe zawiadomienia o takiej bezprawności pochodzące ze źródeł zewnętrznych. W takiej sytuacji, obowiązek zapewnienia zgodności z prawem udostępniania materiałów spoczywać będzie wyłącznie na użytkownikach, którzy je udostępniają z wykorzystaniem serwisu, i to oni ponosić będą za to odpowiedzialność.

Wprowadzenie opisanych już wcześniej mechanizmów oceny zarchiwizowanego dorobku naukowego przed publikacją może jednak ograniczyć lub wyłączyć możliwość powoływania się na art. 14 uśude. $\mathrm{Z}$ przepisu tego nie wynika bowiem jasno, czy przesłanką świadczącą o wiedzy administratora co do bezprawności publikowanych w serwisie materiałów jest jakakolwiek moderacja, czy też musi faktycznie dojść do pozyskania tej wiedzy. A to właśnie posiadanie takiej wiedzy wyłącza możliwość powoływania się na art. 14 uśude. Naszym zdaniem ocena pozaprawnych aspektów publikacji (np. jej „naukowości”) przez osobę niedysponującą wiedzą prawniczą nie może automatycznie doprowadzić do powzięcia wiedzy o bezprawności. Zawsze należy osobno badać, czy osoba badająca uzyskała wiarygodną wiadomość, 
a podejmowane przez nią działania i stan jej wiedzy nie są tu bez znaczenia. Niemniej jednak zdajemy sobie sprawę z dyskusyjności takiego poglądu oraz ryzyka, że na gruncie obecnej treści art. 14 uśude jakakolwiek moderacja może być potraktowana jako powzięcie wiedzy co do bezprawności.

Prowadzenie serwisu musi być ponadto zgodne z innymi przepisami prawa, które mogą mieć tu zastosowanie. Dla przykładu, z uwagi na fakt gromadzenia danych osobowych użytkowników, a być może i odbiorców serwisu, administrator powinien odpowiednio zabezpieczyć te dane i spełnić pozostałe obowiązki wynikające z ustawy o ochronie danych osobowych. Nie są to jednak kwestie specyficzne dla otwartego dostępu i nie będą tu rozwijane.

\subsection{Przykładowe praktyczne rozwiązanie dla jednostki naukowej}

Poniżej prezentujemy przykładowe rozwiązanie pozwalające jednostce naukowej na wprowadzenie otwartego mandatu połączonego z prowadzeniem instytucjonalnego repozytorium. Zakładamy, że chodzi o uczelnię, która dąży do umieszczenia w otwartym dostępie publikacji naukowych tworzonych przez swoich pracowników w ramach ich obowiązków pracowniczych.

Cel ten powinien być realizowany w ramach kompleksowej polityki otwartego dostępu. Najlepszym miejscem na te regulacje jest „Regulamin zarządzania prawami autorskimi i prawami pokrewnymi oraz prawami własności przemysłowej oraz zasad komercjalizacji wyników badań naukowych i prac rozwojowych". Przepisy dają uczelniom swobodę wprowadzenia do takiego regulaminu postanowień dotyczących otwartego dostępu do treści naukowych, publikowanych przez pracowników jednostki. Może to być albo szczegółowa regulacja, albo ogólniejsze wytyczne, które zostaną następnie szczegółowo wykonane w treści indywidualnych umów o pracę lub aneksów do tych umów.

Co istotne, kompetencja do wydania takiego regulaminu nie oznacza, że jednostka może w sposób jednostronny wymusić określone rozwiązania. To raczej postanowienia tych regulaminów wiążą 
jednostki naukowe i wpływają na ich swobodę przy kształtowaniu umów, m.in. z autorami publikacji naukowych. Obecnie niektóre $\mathrm{z}$ tych regulaminów powielają i utrzymują $\mathrm{w}$ mocy ustawowe reguły dotyczące pracowniczych utworów naukowych (art. 14 ust. 1 pr. aut.). Ale przyjęcie przez jednostkę regulaminu potwierdzającego te regulacje oznacza rezygnację $z$ dopuszczonego w tym przepisie innego uregulowania praw w drodze umowy, co utrudni wprowadzenie otwartego dostępu.

Naszym zdaniem, prawidłowa polityka otwartego dostępu zawarta $\mathrm{w}$ takim regulaminie powinna opierać się o art. 14 pr. aut., a nie przepisywać go. Za najbardziej wskazany uważamy opisany wcześniej sposób, który polega na rezygnacji z pierwszeństwa wynikającego $z$ tego przepisu $\mathrm{w}$ zamian za zobowiązanie pracowników do umieszczania $\mathrm{w}$ otwartym dostępie $\mathrm{w}$ repozytorium instytucjonalnym publikacji wydanych przez wybrane przez nich wydawnictwo. Przed wprowadzeniem takiego zobowiązania należy oczywiście zadbać o realną możliwość połączenia otwartego dostępu z publikacją w sposób brany pod uwagę przy ocenie dorobku naukowego. Tylko wtedy polityka otwartego dostępu będzie miała racjonalne uzasadnienie.

Dlatego też należy albo odpowiednio dostosować zasady przyjmowania publikacji przez wydawnictwo uczelniane, albo zapewnić sobie współpracę $z$ akceptującym otwarty dostęp wydawnictwem zewnętrznym. Polityka otwartego dostępu nie powinna zakazywać autorom publikowania $\mathrm{w}$ wydawnictwach sprzeciwiających się otwartemu dostępowi, jednak pod warunkiem podniesienia kwestii otwartego dostępu w negocjacjach, wyczerpującego uzasadnienia wyboru takiego wydawnictwa i wyjaśnienia, dlaczego otwartego dostępu odmówiono. Kolejnym istotnym warunkiem jest udział jednostki naukowej w negocjacjach, w tym w postaci wspierania autorów gotowymi wzorcami umownymi. Zagadnienia te omawialiśmy w podrozdziale 5.1 .

Powyższe kwestie powinny zostać przełożone na prawniczy język postanowień regulaminu „własności intelektualnej” uczelni, a następnie zgodnie $z$ tym regulaminem wpisywane do postanowień umów, $\mathrm{w}$ tym umów o pracę $\mathrm{z}$ naukowcami.

Poza regulaminem „własności intelektualnej” należy przygotować zgodny $z$ właściwymi przepisami osobny regulamin repozyto- 
rium instytucjonalnego (regulamin świadczenia usług drogą elektroniczną). Szczególną uwagę należy w nim poświęcić kwestiom związanym z przyjmowaniem i akceptacją utworów, stanowiących dorobek naukowy użytkowników, do publikacji. Wprowadzenie ewentualnej moderacji lub innych działań prowadzących do zapoznania się $z$ treścią materiałów umieszczanych $\mathrm{w}$ repozytorium przez użytkowników musi być dokonane ze świadomością konsekwencji co do zasad odpowiedzialności uregulowanych $\mathrm{w}$ art. 14 uśude. Raz jeszcze przypominamy, że należy ponadto zapewnić przestrzeganie przepisów o ochronie danych osobowych.

Podsumowując, kluczem do praktycznej realizacji otwartego mandatu jest polityka otwartego dostępu łącząca otwarty mandat, instytucjonalne repozytorium oraz publikację w sposób brany pod uwagę przy ocenie dorobku naukowego. Wymaga to odpowiedniej organizacji uczelnianych wydawnictw oraz współpracy $z$ wydawnictwami zewnętrznymi, a w szczególności wspierania autorów w negocjacjach $z$ wydawcami przeciwnymi otwartemu dostępowi. 


\section{Wdrażanie otwartego dostępu z perspektywy instytucji finansującej badania}

W niniejszym rozdziale omawiamy podstawowe kwestie prawne, jakie napotyka instytucja finansująca badania zamierzająca wprowadzić otwarty dostęp w finansowanych przez siebie projektach.

W pierwszej kolejności omawiamy sposoby wdrożenia otwartego mandatu przez instytucję finansującą (6.1). Następnie prezentujemy podejście alternatywne, polegające na wspieraniu otwartego dostępu jako jednego $z$ fakultatywnych elementów oceny wniosku (6.2). Wreszcie przedstawiamy praktyczne przykładowe rozwiązanie, polegające na współpracy pomiędzy autorami, instytucją finansująca, instytucją naukową oraz wydawnictwem (6.3).

\subsection{Otwarty mandat instytucji finansującej}

Przypomnijmy, że otwartym mandatem nazywamy prawne zobowiązanie autorów utworów naukowych do udostępniania tych utworów w otwartym dostępie. Wprowadzenie otwartego mandatu przez instytucję finansującą jest możliwe na takiej samej zasadzie, jak wprowadzenie każdego innego wymagania dla wnioskodawców, które następnie staje się zobowiązaniem $\mathrm{w}$ umowie stanowiącej podstawę przekazania środków. Instytucja finansująca może zatem określić, że finansuje tylko takie projekty, które zapewnią umieszczenie w otwartym dostępie powstałych w ich wyniku publikacji naukowych.

W przypadku projektów zgłaszanych przez samych autorów publikacji, wykonanie tak sformułowanego otwartego mandatu będzie polegało na przyjęciu przez nich samych zobowiązania do umieszczenia 
publikacji w otwartym dostępie. Kwestie związane z możliwością takiego zobowiązania się analizowaliśmy w rozdziale 3. Dla przykładu, autor będący pracownikiem naukowym musi przed podjęciem takiego zobowiązania uwzględnić ustawowe pierwszeństwo publikacji należne jego instytucji.

Natomiast w przypadku projektów zgłaszanych przez inne podmioty konieczne będzie, aby wnioskodawcy zapewnili sobie odpowiednie uprawnienia do publikacji powstałych $\mathrm{w}$ wyniku projektu w stosunku do zatrudnionych przez siebie naukowców, autorów tych publikacji. Co do możliwości i sposobu zapewnienia tych uprawnień aktualne są uwagi zawarte $\mathrm{w}$ rozdziale 5 . Tam zajmowaliśmy się jednak wdrożeniem otwartego dostępu do całego dorobku naukowego pracowników, podczas gdy w ramach realizacji otwartego mandatu instytucji finansującej wystarczy, że instytucja naukowa zapewni otwarty dostęp jedynie w stosunku do finansowanych przez niego publikacji. Jedno nie wyklucza oczywiście drugiego.

Istotne jest, aby instytucja finansująca dokładnie określiła zakres omawianego tu otwartego mandatu. Zakres ten ma znaczenie zwłaszcza z perspektywy projektów przewidujących komercjalizację wyników badań z wykorzystaniem wyłączności wynikającej z praw na dobrach niematerialnych, jak również projektów dotyczących rozwiązań niejawnych. Uważamy, że możliwe jest realizowanie takich projektów $\mathrm{w}$ połączeniu $z$ wykonaniem otwartego mandatu instytucji finansującej, o ile zakres tego mandatu obejmie jedynie publikacje naukowe powstałe $\mathrm{w}$ związku $\mathrm{z}$ projektem, a nie wszystkie powstałe $\mathrm{w}$ jego ramach dobra niematerialne. Jeżeli bowiem $\mathrm{w}$ wyniku danego projektu powstają publikacje naukowe oznacza to, że kwestie dotyczące komercjalizacji (np. sposób opisania stworzonego w projekcie wynalazku) oraz kwestie ochrony informacji niejawnych zostały już przez wykonawców projektu rozwiązane. Kwestie te nie będą zatem stały na przeszkodzie otwartemu dostępowi.

Podobnie jak w przypadku wdrażającej otwarty mandat instytucji naukowej, nałożenie omawianego zobowiązania przez instytucję finansującą powinno iść $\mathrm{w}$ parze $\mathrm{z}$ uruchomieniem własnego, otwartego repozytorium, chyba że pozwoli się wnioskodawcom na wykonanie mandatu za pomocą repozytoriów instytucjonalnych lub dziedzino- 
wych. Zagadnienia prawne związane $\mathrm{z}$ funkcjonowaniem repozytoriów omawialiśmy w podrozdziale 5.2.

\subsection{Wspieranie otwartego dostępu}

Aktualne przepisy prawa nie zobowiązują instytucji finansujących do nakładania otwartych mandatów, nawet w przypadku finansowania ze środków publicznych. Co prawda, coraz częściej postuluje się wprowadzenie takich przepisów, jednak nadal otwarty mandat jest prawem, a nie obowiązkiem instytucji finansujących naukę. Te, które z różnych powodów nie chcą lub nie mogą nakładać na wnioskodawców otwartego mandatu, mogą natomiast starać się przynajmniej wspierać otwarty dostęp. Polegać to będzie na ustaleniu, że umieszczanie powstałych w wyniku finansowanego projektu publikacji naukowych w otwartym dostępie jest jednym z kryteriów oceny wniosku. W tym przypadku, o finansowanie będą mogły ubiegać się także i projekty niezgodne z założeniami otwartego dostępu. To, komu środki zostaną przyznane, zależeć będzie od łącznej oceny wszystkich kryteriów.

Niemniej jednak, nawet w przypadku wspierania otwartego dostępu należy zadbać, aby wnioskodawca, który deklaruje go jako jeden z elementów upowszechniania wyników projektu, zrealizował tę deklarację. Umowa zawierana $z$ takim wnioskodawcą powinna już zawierać wyraźne zobowiązanie do umieszczenia przedmiotowych publikacji w otwartym dostępie. Podobnie jak w sytuacji omawianej w poprzednim podrozdziale, w przypadku umów zawieranych z wnioskodawcą-autorem, będzie to jego bezpośrednie zobowiązanie. Natomiast w odniesieniu do innych wnioskodawców, będzie to ich zobowiązanie do takiego ukształtowania ich stosunków prawnych z autorami, aby było możliwe umieszczenie $\mathrm{w}$ otwartym dostępie publikacji naukowych stworzonych przez nich w wyniku otrzymanego finansowania.

\subsection{Przykładowe praktyczne rozwiązanie dla instytucji finansującej}

Jako przykład praktycznego wdrożenia otwartego dostępu przez instytucje finansujące naukę proponujemy wpisanie działań tych instytucji 
w ramy proponowanego tu wcześniej rozwiązania, polegającego na wdrożeniu kompleksowej polityki otwartego dostępu przez instytucję naukową. W tym modelu, instytucja finansująca byłaby dodatkowym uczestnikiem ukierunkowanej na otwarty dostęp współpracy pomiędzy autorami, uczelniami i wydawcami.

Szczegóły propozycji sprowadzają się do umieszczenia w regulaminie lub innym dokumencie zawierającym zasady finansowania odpowiednich postanowień. Chodzi o wskazanie, że finansowanie i wspólfinansowanie projektów, w związku z którymi powstają lub są udostępniane publikacje naukowe, będzie udzielane wyłącznie wnioskodawcom, którzy zapewnią otwarty dostęp do tych publikacji. Postanowienie to można doprecyzować wyjaśnieniem, że wymaganie nie obejmuje wszystkich wyników projektu, lecz tylko te, które staną się publikacjami naukowymi.

W dalszej kolejności, postanowienia zgodne z powyższą regulacją powinny znaleźć się we wzorze umowy, jaką instytucja finansująca zawierać będzie $z$ wybranym wnioskodawcą. W tym projekcie należy zatem umieścić zgodne $z$ powyższym regulaminem zobowiązanie wykonawcy do zapewnienia otwartego dostępu do publikacji naukowych powstałych $\mathrm{w}$ związku z projektem.

Należy ponadto zadbać, aby już na etapie składania wniosku wnioskodawca mógł wykazać swoją zdolność do realizacji tego zobowiązania. Chodzi tu w szczególności o to, czy będzie uprawniony do dysponowania prawami autorskimi i ewentualnie innymi prawami związanymi z publikacjami. Dowodem na to może być wyjaśnienie, że wnioskodawca jest lub będzie podmiotem tych praw. Warto jednak wymagać szerszych przygotowań, zwłaszcza w odniesieniu do ubiegających się o finansowanie instytucji naukowych. Można na przykład wymagać przedstawienia kompleksowej polityki otwartego dostępu, zdolnej zapewnić realizację zobowiązań wobec instytucji finansującej. Nie uważamy oczywiście, że powinno się narzucać wnioskodawcom konkretną politykę. O wiele bardziej zasadne jest wymaganie, aby była to polityka skuteczna $\mathrm{w}$ zakresie koniecznym $\mathrm{z}$ punktu widzenia danego projektu.

Instytucja finansująca wdrażająca wyżej opisany otwarty mandat powinna uprzednio zadbać o zorganizowanie własnego repozytorium, 
o ile nie uzna, że inne, instytucjonalne lub dziedzinowe repozytoria będą wystarczające do osiągnięcia zakładanego celu. W podrozdziale 5.2 omawialiśmy kwestie związane z prowadzeniem repozytoriów instytucjonalnych - wiele $z$ tych uwag będzie miało zastosowanie do repozytoriów prowadzonych przez instytucje finansujące naukę.

Szczególnie istotne jest takie wdrożenie otwartego mandatu, aby możliwe było uwzględnianie finansowanych publikacji $\mathrm{w}$ procesie oceny dorobku naukowego autorów, a ponadto w procesie ewaluacji finansowanych instytucji naukowych. $Z$ tego punktu widzenia, proste wymaganie umieszczenia publikacji w którymkolwiek repozytorium nie wydaje się wystarczające. Uważamy za o wiele bardziej wskazane, aby instytucje finansujące wdrażały otwarty mandat w sposób podobny do modelu zaprezentowanego $\mathrm{w}$ rozdziale 5 , to jest łącząc udostępnianie $\mathrm{w}$ repozytorium $\mathrm{z}$ publikacją $\mathrm{w}$ wydawnictwie uznawanym na potrzeby oceny dorobku i ewaluacji jednostki.

Oznacza to, że zasady finansowania nie powinny zakazywać publikacji we współpracy z takimi wydawnictwami, a jedynie wymagać równoległego umieszczenia $w$ repozytorium. Należy wyraźnie dopuścić możliwość współpracy z wydawnictwami działającymi już w otwartym dostępie. Natomiast w przypadku konieczności skorzystania $z$ usług wydawnictwa przeciwnego otwartemu dostępowi, postulujemy mechanizmy podobne do proponowanych już wcześniej uczelniom. Mianowicie, finansujący może dopuścić tego typu projekty do konkursu, o ile wybór zamkniętego wydawnictwa zostanie w nich wyczerpująco uzasadniony, a kwestia otwartego dostępu podniesiona w negocjacjach. Podobnie jak uczelnia, instytucja finansująca może wspierać wnioskodawców w tych negocjacjach, na przykład proponując wzorce umowne. Jest ona w sytuacji o tyle lepszej od uczelni, że to ona jest faktycznie źródłem finansowania projektu w całości lub w części. Często finansowanie to obejmuje także opłaty za wydanie publikacji, pobierane przez wydawców, co ma bezpośrednie przełożenie na pozycję negocjacyjną. 


\section{Aneks}

Prezentujemy tu przykładowe postanowienia, które można wykorzystać $\mathrm{w}$ celu wdrożenia otwartego dostępu w umowach $\mathrm{z}$ wydawcami (7.1) oraz w regulaminach instytucji finansującej (7.2). Należy je jednak traktować jako przykłady, a nie gotowe rozwiązania, gdyż wpisanie ich do istniejącej umowy lub regulaminu bez odpowiedniego dostosowania z pomocą prawnika będzie możliwe tylko w szczególnych okolicznościach. Chodzi nam raczej o pokazanie czytelnikowi ogólnego kształtu i kierunku formułowania umów.

\subsection{Wzór postanowień do umowy z wydawcą}

Poniżej przedstawiamy dwie przykładowe klauzule umowy pomiędzy wydawcą a autorem, których celem jest zachowanie autorowi praw koniecznych do umieszczenia utworu w otwartym dostępie. Pierwsza klauzula pozwala autorowi tylko na otwarty dostęp gratis, podczas gdy druga umożliwia autorowi samodzielne umieszczenie utworu w otwartym dostępie libre.

Prezentowane klauzule są inspirowane stosowanymi przez zachodnie uczelnie gotowymi wzorcami aneksów do umów z wydawcami. My natomiast staraliśmy się użyć na tyle ogólnych sformułowań, aby nasze klauzule można było stosować zarówno w aneksach, jak i w samych umowach. Dlatego też w treści klauzuli nie przesądzamy, czy chodzi o zachowanie praw przez autora, przeniesienie praw zwrotnie na autora, czy też o udzielenie mu licencji. Taki zabieg nie pozwoli oczywiście uniknąć konieczności dostosowania danej klauzuli do treści konkretnej umowy lub aneksu. 


\section{- Otwarty dostęp gratis}

1 Autor jest uprawniony do publicznego udostępniania Utworu tak, aby każdy mógł mieć do niego dostęp w miejscu i w czasie przez siebie wybranym.

2 W celu uniknięcia wątpliwości Strony potwierdzają, że Autor nie jest zobowiązany stosować ograniczeń technicznych w dostępie do udostępnianego przez siebie Utworu, ani nie jest zobowiązany do innego ograniczania korzystania z Utworu przez osoby trzecie zgodnie $z$ właściwymi przepisami o dozwolonym użytku lub o innych wyjątkach przewidzianych w przepisach prawa.

\section{- Otwarty dostęp libre}

1 Autor jest uprawniony do korzystania z Utworu i rozporządzania nim na wszystkich znanych polach eksploatacji, a w szczególności:

a wytwarzania określoną techniką egzemplarzy Utworu, w tym techniką drukarską, reprograficzną, zapisu magnetycznego oraz techniką cyfrowa;

b wprowadzania do obrotu, użyczenia lub najmu oryginału albo egzemplarzy Utworu;

c publicznego wykonania, wystawienia, wyświetlenia, odtworzenia oraz nadawania i reemitowania, a także publicznego udostępniania Utworu w taki sposób, aby każdy mógł mieć do niego dostęp w miejscu i w czasie przez siebie wybranym.

2 Autor jest uprawniony do korzystania i rozporządzania opracowaniami Utworu.

3 Autor jest uprawniony do udzielania licencji na korzystanie z Utworu bez ograniczeń. 


\subsection{Wzór postanowień do regulaminu instytucji finansującej}

Poniżej przedstawiamy przykładowe sformułowanie regulaminu stosowanego przez instytucję finansującą przy przyjmowaniu i ocenie wniosków o przyznanie finansowania. Celem tego sformułowania jest nałożenie otwartego mandatu w odniesieniu do publikacji powstałych w wyniku udzielonego finansowania.

W poniższym przykładzie celem jest zapewnienie otwartego dostępu libre do publikacji. W tym celu, w pkt. 2 wykorzystujemy definicję tego otwartego dostępu przytoczoną tu wcześniej w podrozdziale 2.1. Postanowienie to może być jednak szybko przeformułowane na wariant odnoszący się do otwartego dostępu gratis, poprzez analogiczne wykorzystanie przytoczonej w tamtym podrozdziale definicji tego modelu otwartego dostępu.

1 Finansowanie jest udzielane wnioskodawcom, którzy zapewnią otwarty dostęp libre do publikacji naukowych powstałych w wyniku projektu, o którego finansowanie się ubiegają.

2 Przez otwarty dostęp libre do publikacji naukowych rozumie się rozpowszechnianie ich w taki sposób, aby każdy mógł mieć do nich dostęp w miejscu i w czasie przez siebie wybranym wraz z udzieleniem każdemu licencji na nieograniczone, nieodpłatne i niewyłączne korzystanie $z$ nich oraz $z$ ich ewentualnych opracowań; licencja może zawierać postanowienia nakładające na korzystającego zobowiązania nienaruszające istoty uprawnienia do nieograniczonego, nieodpłatnego i niewyłącznego korzystania, takie jak obowiązek przekazania odbiorcy informacji o twórcy, producencie lub wydawcy, przedmiocie licencji oraz o jej postanowieniach, lub obowiązek udostępnienia odbiorcom przedmiotu licencji lub jego opracowania na takiej samej licencji. 


\section{ceŐ̃N Centrum Otwartej Nauki działa}

w ramach Interdyscyplinarnego Centrum

Modelowania Matematycznego i Komputer-

owego Uniwersytetu Warszawskiego. Tworzy

i rozwija systemy informatyczne stanowiące

infrastrukturę otwartej nauki, udostępnia

treści naukowe, wypracowuje otwarte

modele komunikacji naukowej i dystrybucji

wiedzy, prowadzi badania w zakresie nauk

ścisłych i społecznych.

\section{Dr Krzysztof Siewicz specjalizuje się}

w prawnych aspektach przetwarzania informacji, której to tematyce poświęcił wiele publikacji naukowych oraz praktykę zawodową. Doktorat poświęcony wolności użytkowników programów komputerowych obronił na Uniwersytecie w Lejdzie, w Holandii.

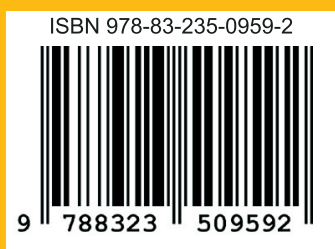

